Argonne National Laboratory

9700 South Cass Avenue

Argonne, Illinois 60439

\title{
ANALYTICAL CHEMISTRY LABORATORY \\ Progress Report for FY 1993
}

Prepared by:

D. W. Green, Manager

A. S. Boparai, Group Leader

D. L. Bowers, Group Leader

D. G. Graczyk, Group Leader

P. C. Lindahl, Group Leader

with contributions from ACL Staff

December 1993

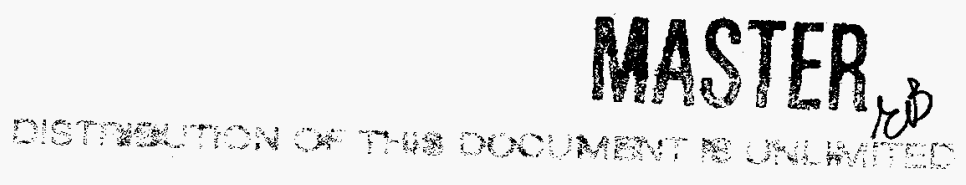




\section{DISCLAIMER}

This report was prepared as an account of work sponsored by an agency of the United States Government. Neither the United States Government nor any agency thereof, nor any of their employees, make any warranty, express or implied, or assumes any legal liability or responsibility for the accuracy, completeness, or usefulness of any information, apparatus, product, or process disclosed, or represents that its use would not infringe privately owned rights. Reference herein to any specific commercial product, process, or service by trade name, trademark, manufacturer, or otherwise does not necessarily constitute or imply its endorsement, recommendation, or favoring by the United States Government or any agency thereof. The views and opinions of authors expressed herein do not necessarily state or reflect those of the United States Government or any agency thereof. 


\section{DISCLAIMER}

Portions of this document may be illegible in electronic image products. Images are produced from the best available original document. 
I. INTRODUCTION $\ldots \ldots \ldots \ldots \ldots \ldots \ldots \ldots \ldots \ldots \ldots \ldots \ldots$

II. ADMINISTRATIVE HIGHLIGHTS $\ldots \ldots \ldots \ldots \ldots \ldots \ldots \ldots$

III. TECHNICAL HIGHLIGHTS $\ldots \ldots \ldots \ldots \ldots \ldots \ldots \ldots \ldots \ldots$

Engineering Studies of Pyrochemical Processes for Integral Fast Reactor Fuels $\ldots \ldots$. 8

Analytical Certification of IFR Special Reference Materials . . . . . . . . . . . 9

Biology's Animal Orphan Waste $\ldots \ldots \ldots \ldots \ldots \ldots \ldots \ldots \ldots \ldots \ldots$

IFR Workshop on Analytical Chemistry $\ldots \ldots \ldots \ldots \ldots \ldots \ldots \ldots \ldots \ldots$

Incinerator Monitoring for Organic Analytes $\ldots \ldots \ldots \ldots \ldots \ldots \ldots \ldots \ldots$

Development of Improved Analytical Methods for the Determination of Actinides in Environmental Matrices $\ldots \ldots \ldots \ldots \ldots \ldots \ldots \ldots \ldots \ldots \ldots$

Analysis of Environmental and Waste Samples . . . . . . . . . . . . 14

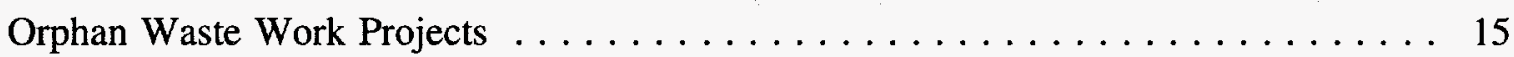

Development of the Integrated Performance Evaluation Program $\ldots \ldots \ldots \ldots \ldots$

Method Development for Waste Isolation Pilot Plant . . . . . . . . . . . . . 19

Determination of Low-Molecular-Weight Analytes in Waste-Drum

Headspace Gas for WIPP Project . . . . . . . . . . . . . . . . 20

Determination of Volatile Organic Compounds in Headspace Gas for

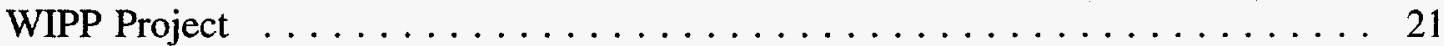

Holding Time Study of Volatile Organics in Canisters for WIPP Samples . . . . . 21

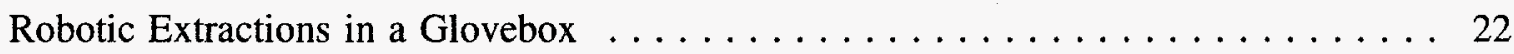

Support for High-Temperature Superconductor Development $\ldots \ldots \ldots \ldots \ldots \ldots$

Methodology for Characterizing Chlorofluorocarbons in Polyurethane Foam . . . . . 24

Studies of TRU.Spec and RE.Spec Chromatography $\ldots \ldots \ldots \ldots \ldots \ldots \ldots$ 


\section{TABLE OF CONTENTS}

Analysis of Simulated Nuclear Waste Glasses and Slags $\ldots \ldots \ldots \ldots \ldots$

Characterization of Used Filters for Disposal $\ldots \ldots \ldots \ldots \ldots \ldots \ldots$

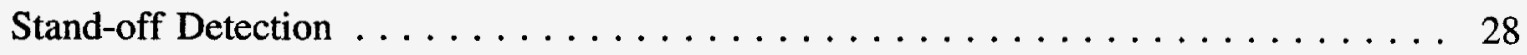

Characterization of Products and Residues from Automobile Shredder

"Fluff" Recycling . . . . . . . . . . . . . . . . . . . . . . . . . . . . . 29

Analysis of Environmental Samples for the U.S. Department of Agriculture . . . . . . 30

Radiochemical Method Evaluation and New Method Development ......... 31

Automated, Real-Time Analysis of Chemical Sensor Data . . . . . . . . . . . 31

X-ray Diffraction Analyses $\ldots \ldots \ldots \ldots \ldots \ldots \ldots \ldots \ldots \ldots \ldots \ldots \ldots \ldots$

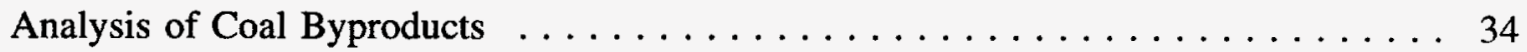

Treatment of Cesium-Contaminated Milk . . . . . . . . . . . . 34

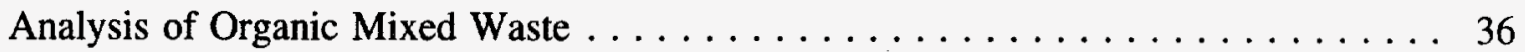

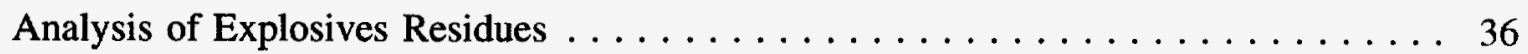

Calcium Isotopic Determination in Canine Bone and Blood Serum . . . . . . . . 37

Computer Generation of Reporting Forms for Environmental Analysis $\ldots \ldots \ldots \ldots$

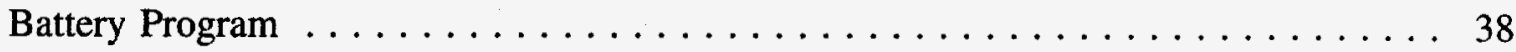

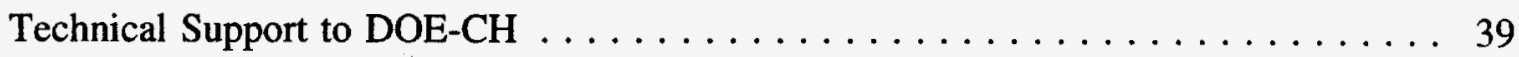

Advanced Photon Source Thrust Group . . . . . . . . . . . . . . . 40

Workshop on Hyphenated Techniques $\ldots \ldots \ldots \ldots \ldots \ldots \ldots \ldots \ldots \ldots$

Analytical Chemistry Support for Emergency Response and Investigation . . . . . . 42

Facility Closure Activities $\ldots \ldots \ldots \ldots \ldots \ldots \ldots \ldots \ldots \ldots \ldots \ldots \ldots$ 


\section{TABLE OF CONTENTS}

$\underline{\text { Page }}$

Review of Quality Assurance Plans $\ldots \ldots \ldots \ldots \ldots \ldots \ldots \ldots \ldots \ldots$

Analytical Laboratory at Aberdeen Proving Grounds . . . . . . . . . . . 45

Environmental Audits $\ldots \ldots \ldots \ldots \ldots \ldots \ldots \ldots \ldots \ldots \ldots \ldots$

Environmental Monitoring Program $\ldots \ldots \ldots \ldots \ldots \ldots \ldots \ldots$

IV. QUALITY ASSURANCE $\ldots \ldots \ldots \ldots \ldots \ldots \ldots \ldots \ldots \ldots \ldots \ldots \ldots$

V. PROFESSIONAL ACTIVITIES $\ldots \ldots \ldots \ldots \ldots \ldots \ldots \ldots \ldots \ldots$

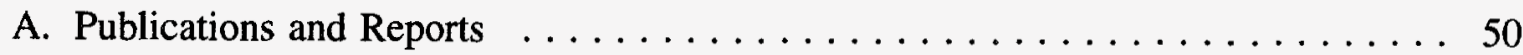

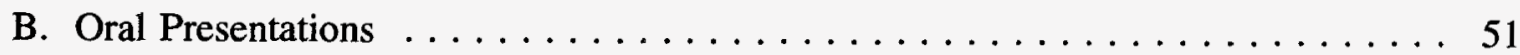

C. Meetings Attended $\ldots \ldots \ldots \ldots \ldots \ldots \ldots \ldots \ldots \ldots \ldots \ldots \ldots$

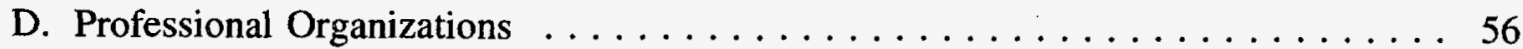

E. Professional Training $\ldots \ldots \ldots \ldots \ldots \ldots \ldots \ldots \ldots \ldots \ldots \ldots$

F. ACL Seminars .......................... 59 


\section{LIST OF FIGURES}

\section{$\underline{\text { Page }}$}

1. Analytical Chemistry Laboratory Organization Chart $\ldots \ldots \ldots \ldots \ldots 2$

2. Total ACL Funding History $\ldots \ldots \ldots \ldots \ldots \ldots \ldots \ldots \ldots \ldots$

3. Analytical Chemistry Laboratory FY 1993 Effort $\ldots \ldots \ldots \ldots \ldots \ldots 7$

4. Analytical Chemistry Laboratory FY 1993 Total Operating Costs . . . . . 7 


\section{INTRODUCTION}

The purpose of this report is to summarize the activities of the Analytical Chemistry Laboratory (ACL) at Argonne National Laboratory (ANL) for Fiscal Year (FY) 1993 (October 1992 through September 1993). This annual report is the tenth for the $\mathrm{ACL}^{1}$ and describes continuing effort on projects, work on new projects, and contributions of the ACL staff to various programs at ANL.

The Analytical Chemistry Laboratory is a full-cost-recovery service center, with the primary mission of providing a broad range of analytical chemistry support services to the scientific and engineering programs at ANL. The ACL also has research programs in analytical chemistry, conducts instrumental and methods development, and provides analytical services for governmental, educational, and industrial organizations. The ACL handles a wide range of analytical problems. Some routine or standard analyses are done, but it is common for the Argonne programs to generate unique problems that require development or modification of methods and adaption of techniques to obtain useful analytical data.

The ACL is administratively within the Chemical Technology Division (CMT), its principal ANL client, but provides technical support for many of the technical divisions and programs at ANL. The ACL has four technical groups--Chemical Analysis, Instrumental Analysis, Organic Analysis, and Environmental Analysis--which together include about 45 technical staff members (see Fig. 1). Talents and interests of staff members cross the group lines, as do many projects within the ACL.

\footnotetext{
${ }^{1}$ Reports for FY 1984 through FY 1994 are: ANL/ACL-85-1 (March 1985), ANL/ACL-85-4 (December 1985), ANL/ACL-86/2 (November 1986), ANL/ACL-87-2 (December 1987), ANL/ACL88-1 (December 1988), ANL/ACL-89/6 (December 1989), ANL/ACL-90/2 (December 1990), ANL/ACL-91/1 (December 1991), and ANL/ACL-92/4 (December 1992).
} 
F. J. Martino QA/QC Coordinator

\begin{tabular}{||l|}
\hline \multicolumn{1}{|c|}{$\begin{array}{c}\text { CHEMICAL ANALYSIS } \\
\text { D. G. Graczyk, } \\
\text { Group Leader }\end{array}$} \\
\hline A. M. Essling \\
\hline I. M. Fox \\
\hline D. R. Huff \\
\hline E. A. Huff \\
\hline P. L. Johnson \\
\hline F. P. Smith \\
\hline C. T. Snyder \\
\hline L. E. Ross ${ }^{\text {sta }}$ \\
\hline C. M. Stevens ${ }^{\text {sta }}$ \\
\hline \hline
\end{tabular}

\begin{tabular}{||l||l|}
\hline \multicolumn{1}{|c|}{$\begin{array}{c}\text { INSTRMENTAL ANALYSIS } \\
\text { D. L. Bowers, } \\
\text { Group Leader }\end{array}$} \\
\cline { 2 - 3 } F. Markun \\
\hline C. S. Sabau \\
\hline L. L. Smith \\
\hline W. E. Streets \\
\hline B. S. Tani \\
\hline T. TenKate \\
\hline J. S. Yaeger \\
\hline H. T. Goodspeed ${ }^{\text {STA }}$ \\
\hline R. R. Heinrich \\
\hline STA \\
\hline S. Siegel ${ }^{\text {STA }}$ \\
\hline
\end{tabular}

\begin{tabular}{||l||l|}
\hline \multicolumn{1}{|c|}{$\begin{array}{c}\text { ORGANIC ANALYSIS } \\
\text { A. S. Boparai, } \\
\text { Group Leader }\end{array}$} \\
\cline { 2 - 3 } & D. V. Applegate \\
\hline S. E. Carpenter \\
\hline L. L. Chromizky \\
\hline J. C. Demirgian \\
\hline E. Y. Hwang \\
\hline S. D. Kent \\
\hline K. J. Parish \\
\hline G. T. Reedy \\
\hline Y. Tsai \\
\hline J. A. Everhart ${ }^{\text {SERS }}$ \\
\hline M. A. Gritters \\
\hline S. M. Macha ${ }^{\text {RAS }}$ \\
\hline E. Vinokour ${ }^{\text {TTA }}$ \\
\hline
\end{tabular}

ADMINISTRATIVE/CLERICAL/ SECRETARIAL SUPPORT

V. A. Mendez

L. Barbosa

A. M. Birmingham

L. L. Lane LA $^{\text {TA }}$

H. L. Terdic

F. L. King ${ }^{\text {HSA }}$
W. GREEN

\begin{tabular}{||l||}
\hline $\begin{array}{c}\text { ENVIRONMENTAL ANALYSIS } \\
\text { P. C. Lindahl, } \\
\text { Group Leader }\end{array}$ \\
\hline D. A. Bass \\
\hline J. S. Crain \\
\hline J. J. Marr \\
\hline L. B. TenKate \\
\hline R. W. Bane \\
\hline K. J. Jensen \\
\hline JTA Sedlet \\
\hline
\end{tabular}

$\overline{\mathrm{TA}}=$ Term Appointee; HSSA $=$ High School Student Aide; STA = Special Term Appointee; SERS = Science and Engineering Research Semester; CS = Co-op Student; RAS $=$ Research Aide Senior.

Fig. 1. Analytical Chemistry Laboratory Organization Chart 
The Chemical Analysis Group uses wet-chemical and instrumental methods for elemental, compositional, and isotopic determinations in solid, liquid, and gaseous samples and provides specialized analytical services. Major instruments in this group include: an ion chromatograph (IC), an inductively coupled plasma/atomic emission spectrometer (ICP/AES), spectrophotometers, mass spectrometers (including gas-analysis and thermal-ionization mass spectrometers), emission spectrographs, autotitrators, sulfur and carbon determinators, and a kinetic phosphorescence uranium analyzer.

The Instrumental Analysis Group uses nuclear counting techniques in determining the radiochemical constituents in a wide range of sample types, from environmental samples with low radioactivity to samples with high radioactivity that require containment. Other types of determinations use X-ray diffraction and fluorescence of solids. Major instrumentation includes: nuclear detectors, a variety of multichannel analyzers and associated counting equipment, X-ray diffractometers, energy dispersive $\mathrm{X}$-ray analyzers, and a scanning electron microscope. Radioactive samples can be analyzed using ICP/AES or IC.

The Organic Analysis Group uses a number of complementary techniques to separate and to measure, at the trace level, organic compounds. Samples that can be analyzed include complex organic mixtures and compounds, pesticides, potentially hazardous wastes, and drugs. Major instrumentation in this group includes: gas chromatograph/mass spectrometer (GC/MS) systems, Fourier transform infrared (FTIR) spectrometers, a GC/matrix-isolation FTIR/MS (GC/MI-IR/MS) instrument, GCs, an FTIR microscope, high-performance liquid chromatographs, a supercritical fluid extraction (SFE) apparatus, liquid chromatography/mass spectrometry system (LC/MS), and a supercritical fluid chromatograph (SFC). Facilities exist for analysis of radioactive samples. Highly radioactive samples can be treated to separate the organic and radioactive constituents. Organic 
Analysis Group personnel also develop methods for such purposes as continuously monitoring incinerator emissions, detecting organic compounds remotely and performing rapid on-site determination of organic constituents with FTIR spectrometers, and determining volatile organic compounds (VOCs) in the headspace gas of DOE waste containers.

The Environmental Analysis Group performs analyses of environmental, hazardous waste, and coal samples for the inorganic constituents. Major instrumentation in this group includes: atomic absorption spectrophotometers (AAS) equipped with flame, flameless, cold-vapor mercury, and hydride-generation capabilities; toxicity characteristic leaching procedure (TCLP) extraction facilities; an automated carbon/hydrogen/nitrogen (CHN) analyzer; an inductively coupled plasma/mass spectrometer (ICP/MS); and a sulfur determinator.

In FY 1993, the ACL received samples requiring multigroup efforts. Typical of those samples are "orphan" waste samples whose ownership and composition are unclear, and samples in support of ANL's decontamination, decommissioning, and cleanup activities.

The ACL has a sample-receiving system that allows efficient processing of environmental and hazardous and mixed waste samples, including chain-of-custody procedures. The ACL also has quality assurance (QA) and associated quality control (QC) systems in place to produce data packages that meet the reporting requirements of the Environmental Protection Agency (EPA), Department of Energy (DOE), and other similar organizations. 


\section{ADMINISTRATIVE HIGHLIGHTS}

The ACL is both a full-cost-recovery service center in support of ANL programs and an organization doing research and development in support of DOE programs. Generally, funding for ACL research is included as part of CMT's total budget. In FY 1993, the total funding for the ACL increased to its highest level, as shown in Fig. 2.

The ACL recovered $100.2 \%$ of its total operating costs in FY 1993. Over the last decade, the ACL has recovered $97.0 \%$ of its costs. Approximately $60 \%$ of the income of the ACL in FY 1993 came from service work through ANL programs, and the remainder came directly to the ACL from DOE, other DOE sites, other federal agencies, and external users of ACL services. The ACL effort, including divisional administration, includes about one-half recoverable time (sales to users in Fig. 3). Figure 4 gives a breakdown of the total operating costs for FY 1993, which are largely effort related.

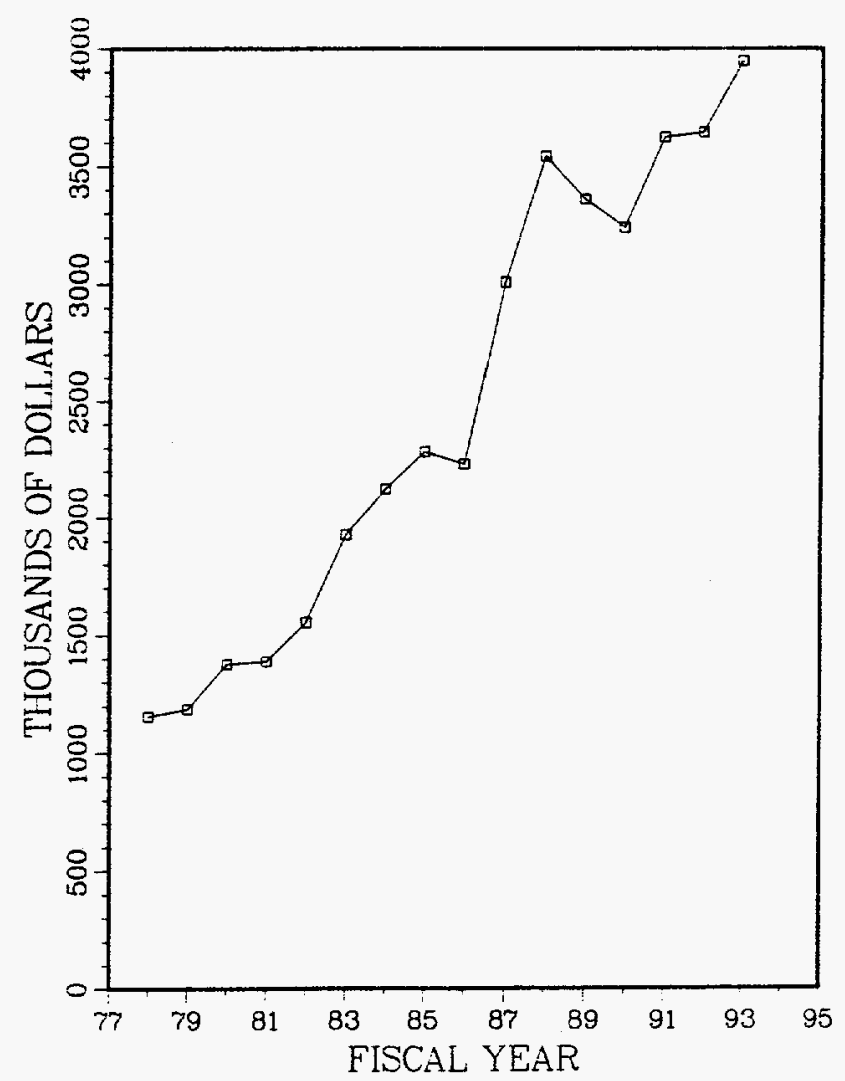

The ACL obtained valuable help from the nine Special Term Appointees (see Fig. 1) in Fig. 2. Total ACL Funding History FY 1993 to assist with load leveling. The STAs, which include several retired ACL staff, provided about one full-time equivalent of assistance in FY 1993. In addition, four students and co-ops, one 
high-school faculty member, and one college faculty member supplemented the regular ACL staff in FY 1993 (not all are included in Fig. 1).

New ACL capabilities established in FY 1993 include additional laboratory facilities for analysis of radioactive samples for organic constituents, a laboratory robotics system, a mercury analyzer, and a facility for sample preparation using closed-vessel microwave-heated digestion.

Two projects were completed in FY 1993 with Support Development Funds from ANL. In the first, the performance of the ACL's ICP/MS system was evaluated for its ability to determine trace elements in solution. In the second, the distribution coefficients for inorganic cations on extraction columns containing TRU•Spec and RE•Spec resins were determined so that the ACL would have better capability to separate selected elements in these columns.

The ACL, as part of an ongoing program, improved the efficiency and safety of its operations in FY 1993. Waste materials and samples for which no "owner" could be determined were eliminated from ACL laboratories through the ANL "Orphan Waste" program. New hand-and-foot monitors were purchased and installed to provide additional protection against unintended movement of radioactive materials from ACL laboratories. The ANL Transportation Safety Manual was implemented for analytical samples, and a memorandum was issued to all ACL clients giving guidance. Occupation of renovated office and laboratory facilities for staff of the Chemical Analysis and Environmental Analysis Groups was completed. A new hood in the sample receiving area was installed to provide for safer operations. Regular inspections of work areas by ACL personnel, as well as other ANL and DOE personnel, resulted in improvements of the ACL facilities and operating procedures with respect to environmental, safety, and health matters. A management appraisal on the use of bound notebooks resulted in changes that will improve the ACL's ability to retrieve laboratory data on samples that were previously analyzed. 


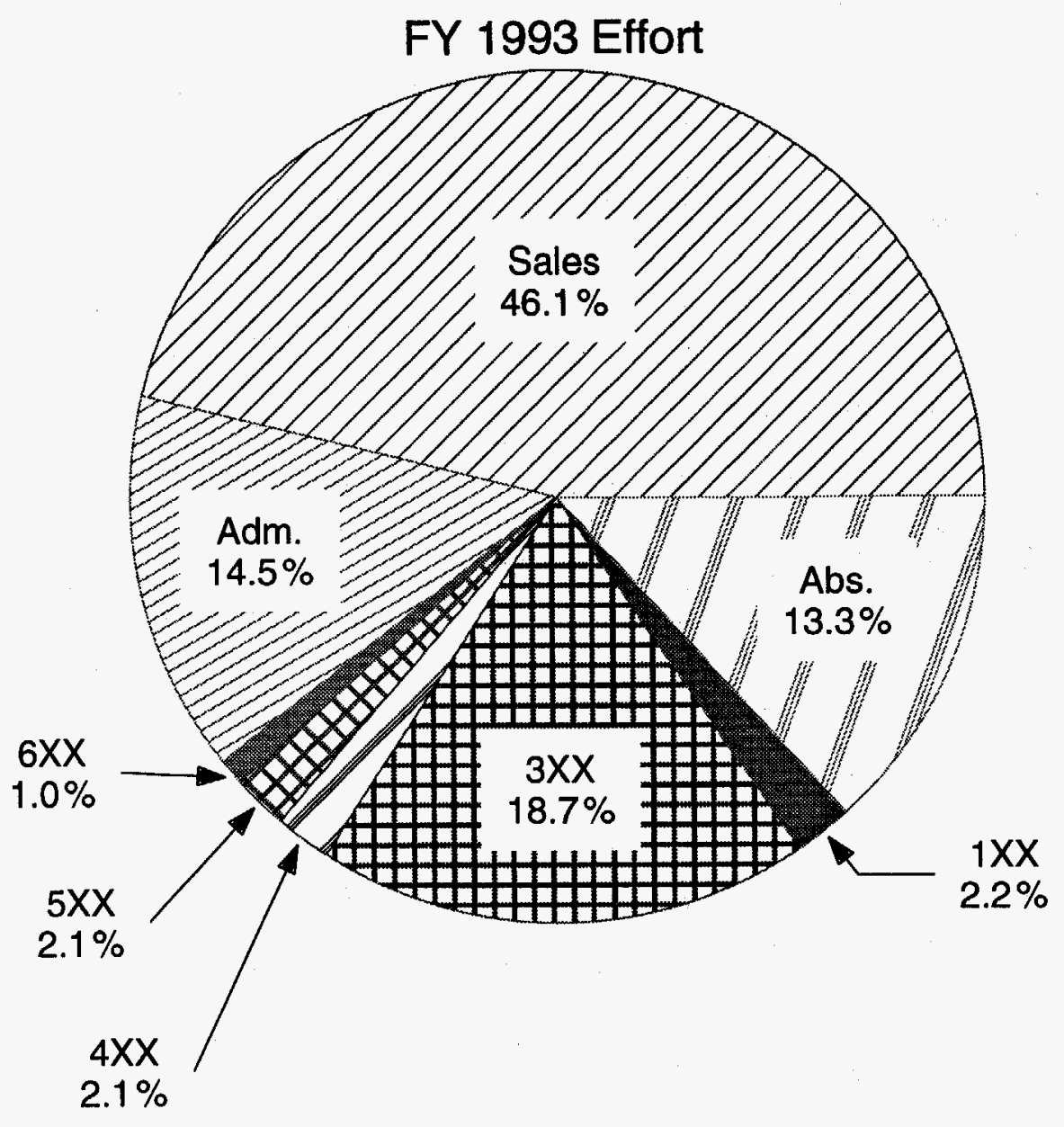

Fig. 3. Analytical Chemistry Laboratory FY 1993 Effort

Adm $=$ administration

Abs $=$ absences

$1 \mathrm{XX}=$ operations administration

$3 X X=$ analytical overhead; e.g., instrument maintenance

$4 X X=$ non-analytical overhead; e.g., safety

$5 \mathrm{XX}=$ professional activities

$6 \mathrm{XX}=$ experimentation

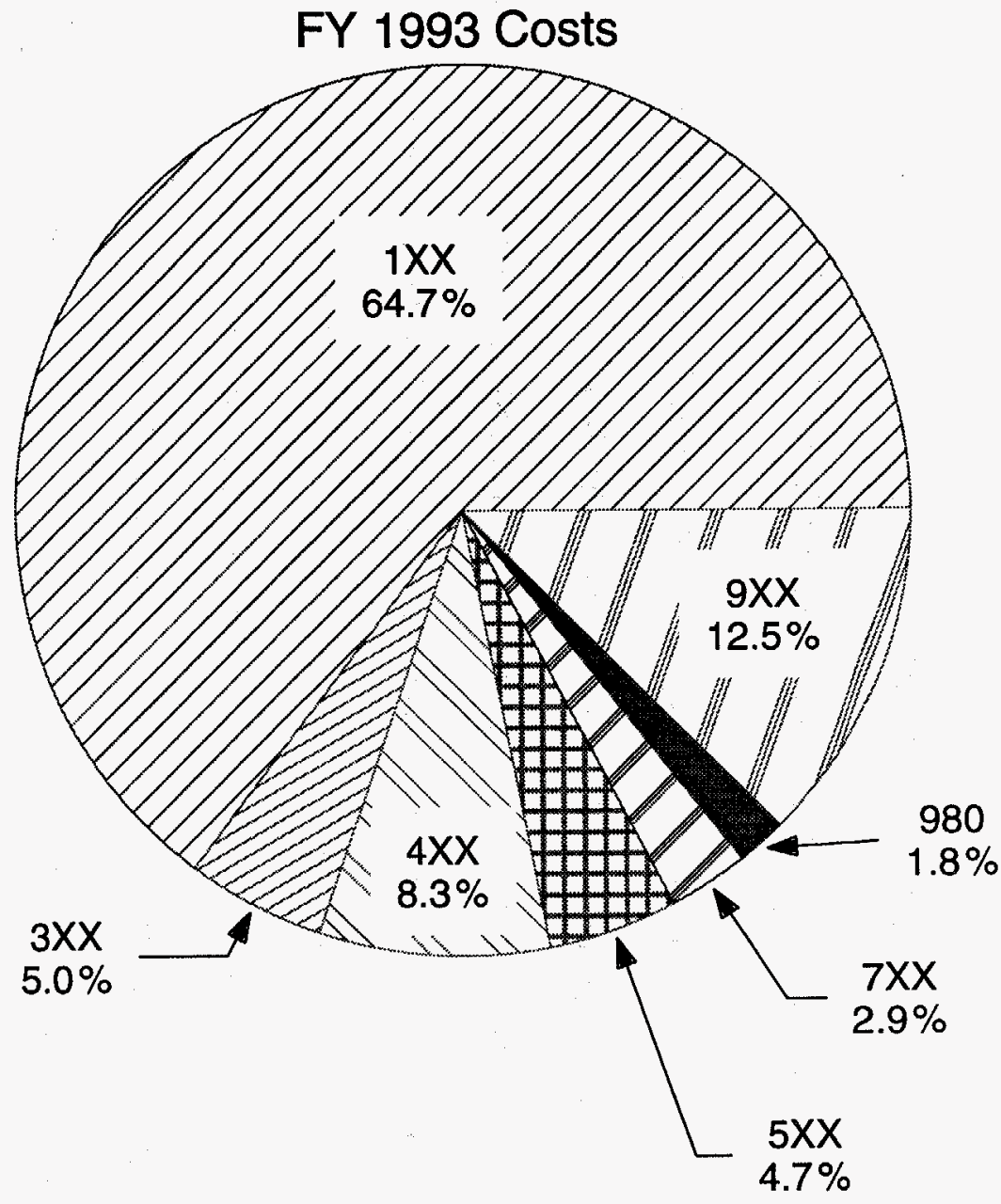

Fig. 4. Analytical Chemistry Laboratory FY 1993 Total Operating Costs

$1 \mathrm{XX}=$ salaries and fringes

$3 \mathrm{XX}=$ materials and services

$4 X X=$ services, subcontracts, etc.

$5 \mathrm{XX}=$ shopwork and work projects

$7 \mathrm{XX}=$ redistributions

$9 \mathrm{XX}=$ indirect costs

980 = intradivisional allocation 


\section{TECHNICAL HIGHLIGHTS}

Engineering Studies of Pyrochemical Processes for Integral Fast Reactor Fuels (D. L. Bowers, C. S. Sabau, J. S. Crain, and F. P. Smith)

In the electrorefining of spent fuels for the Integral Fast Reactor (IFR), metallic fuel pins (U, $\mathrm{Pu}, \mathrm{Zr}$ ) are chopped into small segments and placed into a basket that is introduced into molten salt $(\mathrm{LiCl}+\mathrm{KCl})$ at $500^{\circ} \mathrm{C}$. The basket is connected to a dc power supply and made anodic; nearly pure uranium is removed from the spent fuel by electrotransport to solid cathodes, followed by electrotransport of the plutonium and any remaining uranium to liquid cadmium cathodes. Engineering-scale studies of this electrorefining process are being conducted in CMT to develop models that can predict the recovery of $\mathrm{U}$ and $\mathrm{Pu}$ as well as the decontamination of these elements from fission-product elements and process materials. The ACL has contributed to this effort by determining elements of interest in samples from the halide-salt electrolyte, cadmium anode, and the cathode product. Special dissolution procedures are followed for each type of sample matrix, and separation schemes based on solvent extraction and ion exchange are used to isolate the desired elements from matrix components and, subsequently, to separate these elements. Cations, including uranium and plutonium, are determined in IFR samples with an ICP/AES instrument configured to analyze radioactive solutions. The mass spectrometric isotope dilution (MSID) technique is used whenever higher precision and accuracy than attainable with ICP/AES are required. The ICP/MS is used when the concentrations of uranium and rare earth are below the detection limits of the ICP/AES instrument.

Experiments to which ACL contributed during the past year include tests of salt stripping, U$\mathrm{Zr}$ co-deposition, and the liquid cathode performance. In the salt stripper tests, lithium metal was added to the spent salt from an engineering-scale IFR electrorefiner to remove uranium and rare earths. This removal process is necessary prior to salt disposal. Analytical data generated from 
samples taken during these tests provided insight on the behavior of uranium and rare earths with repeated electrotransport cycles. Zirconium from the spent IFR fuel also builds up and must be removed for recycling. Uranium-zirconium deposition on a solid cathode was demonstrated under different operating conditions in the engineering-scale electrorefiner. Analytical data provided information as to the most favorable conditions for U-Zr transport to the solid cathode. The liquid cathode performance was investigated by varying the U/Pu ratio in the electrorefiner salt. Starting with only plutonium in the salt, the electrorefiner was operated using liquid cadmium as the cathode. Uranium was added in increments to vary the amount of uranium in each test run. Samples were taken from the liquid cathode and analyzed for $\mathrm{U}$ and $\mathrm{Pu}$ content. These data provided insight on the amount of each actinide transferred to the cathode and liquid cathode performance under the electrorefiner conditions expected in IFR fuel reprocessing.

Analytical Certification of IFR Special Reference Materials (A. M. Essling, D. G. Graczyk, E. A. Huff, F. P. Smith, D. L. Bowers, and C. S. Sabau)

The Analytical Laboratory in the Fuels and Engineering Division at ANL-West is developing methods for analyses that will be required for process control and materials accountability during the planned demonstration of the IFR fuel cycle. To help in their methods development and to provide a source of quality-control samples for use during the fuel-cycle demonstration, the Chemical Technology Division (J. Ackerman et al.) is preparing several sets of "Special Reference Materials," each consisting of specified analytes in a matrix typical of samples that will be generated during electrorefiner operations at the IFR Fuel Cycle Facility of ANL-West. It is the task of the ACL to characterize each batch of materials by chemical analysis and provide reference values for the concentrations of individual constituents in each matrix.

During FY 1993, batches of two special reference materials were prepared and poured into nominally one-gram samples by the CMT workers. One of these, designated SRM-A, contains 
enriched uranium in a $\mathrm{LiCl}-\mathrm{KCl}$ salt matrix, while the other, SRM-B, has the same salt matrix but contains $\mathrm{U}, \mathrm{Pu}, \mathrm{Am}$, and a mixture of simulated fission-product and process elements such as rare earths, alkali metals, and transition metals. To provide accurate and precise $\mathrm{U}$ and $\mathrm{Pu}$ assays in this work, we are applying the MSID method with a special internal-standard technique for the massspectrometric uranium measurements.

All of the uranium isotopic and compositional analyses on SRM-A have been completed. The results of uranium assays on ten SRM-A samples analyzed in duplicate showed a mean concentration of $2.5058 \mathrm{wt} \% \mathrm{U}$, with a standard deviation of $0.0022 \mathrm{wt} \%$. The group of 185 SRM-A "standards" that remained after these ten were analyzed was shipped to ANL-West, where they will be used for testing and validating methodology under development for comparable uranium assays. Plutonium measurements on SRM-B have almost been completed. The remaining plutonium determinations are to be completed in FY 1994 along with those of uranium and all the other constituents of this more complicated, multiple-element reference material.

Biology's Animal Orphan Waste (F. Markun, D. V. Applegate, T. TenKate, J. S. Yaeger, M. A. Gritters, K. J. Parish, S. D. Kent, and L. L. Chromizky)

The Biological and Medical Research Division (BIM) has a large collection of rats, mice, and other animals stored in their facility. The animals were preserved with formaldehyde and glycol in 5-gal (19 L) stainless steel containers. These containers of "pickled rats," which date back to the late 1940 s and early 1950 s, resulted from studies of the effects of radiation on animals. Little or no documentation was available to identify the contents of these $\sim 200$ containers, so they qualified as "orphan" unknown wastes in the ANL program to eliminate orphan wastes. The disposal of these wastes required characterization prior to shipment and burial, in this case, at the Hanford site in Washington. 
The ACL prepared a sampling and analysis plan for this effort. This plan included first collecting for radiochemical analysis from each of the containers a $250-\mathrm{mL}$ portion of the preservative liquid along with two $40-\mathrm{mL}$ aliquots for organic analysis. From these samples, various analyses were performed. The liquids from selected samples were analyzed to determine formaldehyde, the type of glycol and other fixative agents, and volatile organic compounds. All samples were analyzed for their radioactive constituents by using gross alpha/beta counting and gamma spectrometry. These analyses showed that 128 containers had measurable beta/gamma radiation. To quantify the relationship between radioactive isotopes in the preservative solution and the amount of radioactivity in the animal carcasses, the calcium level was also determined in the preservative solutions. The published literature indicates that calcium and other bone-seeking elements such as $\mathrm{Sr}$ and Ra leach out when stored for long periods of time in formaldehyde. By determining the isotope-to-calcium ratio in the liquid, we could calculate the amount of radioactivity per animal and container.

The analytical data showed that the majority of the liquids contained ${ }^{226} \mathrm{Ra}$ and $/$ or ${ }^{90} \mathrm{Sr} /{ }^{90} \mathrm{Y}$. Other radionuclides detected at lower concentrations were ${ }^{235} \mathrm{U},{ }^{233} \mathrm{U},{ }^{241} \mathrm{Am}$, and ${ }^{232} \mathrm{Th}$. We found that 128 containers have measurable beta/gamma radiations above background and suspected that some of the canisters may have up to microcurie quantities of ${ }^{239} \mathrm{Pu}$. The project was successfully completed when the waste was shipped to the DOE Hanford site. This waste, which had both radioactive and hazardous constituents, was the first shipment to be sent from ANL-East and the first shipment to be accepted by the Hanford site.

IFR Workshop on Analytical Chemistry (A. M. Essling and D. W. Green)

A workshop on the "Analytical Chemistry of the IFR Process" was jointly organized by staff from the ACL and the Analytical Laboratory at ANL-West (S. Johnson and J. Krsul) and was held in Idaho Falls from March 1 through 3, 1993. The objective of the workshop was to explore the 
technical issues at the interface between the generators and users of analytical data. Thirty-two technical papers were presented and 55 individuals attended from ANL-East and ANL-West.

Incinerator Monitoring for Organic Analytes (J. C. Demirgian, Z. Mao, E. Y. Hwang, G. T. Reedy, and C. T. Snyder)

This project addresses the need mandated by the Clean Air Act of 1990 to monitor air toxic substances emitted from incinerator stacks or other thermal treatment systems. The objective is to develop an analytical system consisting of an FTIR spectrometer combined with a heated long-path cell for use as a continuous emission monitor of the organic products of incomplete combustion (PICs) from incinerators. To provide the required on-stream analysis for incinerators, improvements in FTIR technology were needed.

An on-stream monitor for stack effluent would provide information on incinerator status in near real time. On-stream analysis of the incinerator effluent would simultaneously satisfy the requirements of the Clean Air Act of 1990 and address public concern about incinerator safety. The on-stream monitor might also eliminate the need for a trial burn and the associated cost of demonstrating the destruction and removal efficiency of the incinerator with the more costly sampling and analysis used under current procedures.

In FY 1992, the FTIR technology was advanced in the following areas: (1) testing cell materials for chemical compatibility with hydrogen chloride, (2) characterizing flue-gas PICs, (3) interpreting and evaluating data quality, and (4) developing analysis software. Construction of the prototype equipment for field use was initiated.

In FY 1993, the first prototype FTIR monitor was constructed and field tested in the Toxic Substances Control Act (TSCA) incinerator at the K-25 site (Oak Ridge, Tennessee). All instrumentation and software performed satisfactorily during the testing. The cell required no alignment, cleaning, or repairs--a key advance in the application of this technology. Tests were 
completed to determine the number of background samples and calibration standards that are required to comply with the EPA performance specifications.

We provided input for a protocol to be used with an FTIR continuous emission monitor developed by the EPA. The protocol was converted into a standard operating procedure (SOP) for the field test at K-25. Major advances have been made in validating calibration standards and generating a quantitative spectral library. An effort is in progress to commercialize the instrument developed in this program through a cooperative research and development agreement (CRADA).

We will construct an improved instrument and improved data processes systems based upon the experience obtained at the K-25 test. We will expand the advanced data analysis to include a thorough comparison of classical least squares (CLS) and partial least squares (PLS) algorithms in the spectral domain. In addition, we will initiate data analysis in the time domain. The data collected at the K-25 test will be compared with data obtained using our laboratory incinerator, which offers the advantage of operation under controllable and reproducible conditions. The laboratory incinerator can be configured to simulate an upset condition in the field incinerator operation. The EPA protocol will be further improved with the objective of completing development of an acceptable method for FTIR continuous emission monitoring.

Development of Improved Analytical Methods for the Determination of Actinides in Environmental Matrices (L. L. Smith, J. S. Yaeger, and J. S. Crain)

During the past decade, DOE's environmental restoration and waste management mission has increased in importance and cost. The DOE has budgeted billions of dollars for these efforts and has forecasted that over a million analytical measurements will be required annually. It is only through the development and implementation of new technologies that the anticipated high costs of these measurements can be contained. In an ongoing collaborative effort with the Chemistry Division (P. 
Horwitz, H. Diamond, M. Dietz, R. Chiarizia, and A. Rollins), efficient cost-effective methods using extraction chromatography are being developed to determine actinides in environmental samples.

The feasibility of using Tru•Spec and Teva•Spec resins (Eichrome Industries, Inc.) in extraction chromatographic methods has been demonstrated. However, several limitations were identified. Both the acid concentrations and volumes utilized in these methods are significantly lower than those required for traditional methods, as described in HASL-300 ["Procedures Manual (HASL300)," 27th ed., Environmental Measurements Laboratory, U.S. Department of Energy, New York, 1990]. Whereas this is desirable from a waste minimization viewpoint, it is very difficult to maintain many soil samples in solution under these conditions. Furthermore, experience at ANL has shown that the sample dissolution technique affects chromatographic column behavior.

To address these problems, we are investigating the use of diphonix resin (Eichrome Industries, Inc.). Diphonix exhibits excellent selectivity for the actinides and lanthanides in hydrochloric acid. Larger solution volumes may also be practically employed with this resin. To ensure widespread applicability of this preconcentration method, we are testing it with a variety of soils. Each soil sample is being processed by several dissolution techniques, namely, use of a hot plate, mixed-acid leach procedure, microwave digestion, and total-dissolution fusion. We are developing a separation scheme for the actinide elements utilizing extraction chromatography resins; this scheme will satisfy the requirements of both radiometric and nonradiometric detection methods.

Analysis of Environmental and Waste Samples (D. G. Graczyk, A. G. Engelkemeir, A. M. Essling, A. T. Sherren, I. M. Fox, E. A. Huff, F. P. Smith, L. E. Ross, P. C. Lindahl, J. J. Marr, L. B. TenKate, R. W. Bane, D. A. Bass, K. J. Jensen, R. R. Heinrich, W. E. Streets, A. S. Boparai, P. M. Aznavoorian, G. A. Baudino, L. L. Chromizky, G. T. Reedy, D. V. Applegate, Y. Tsai, M. Clapper-Gowdy, C. T. Snyder, F. J. Martino, L. L. Smith, F. Markun, J. S. Yaeger, D. R. Huff, T. TenKate, K. J. Parish, and S. D. Kent)

The ACL provided analytical services to a variety of environmental monitoring, characterization, and remediation projects administered by the Environmental Research, Energy 
Systems, and Environment/Waste Management (EWM) Divisions at ANL and programs at other DOE facilities (Nevada Test Site and Idaho National Engineering Laboratory). Samples processed during FY 1993 included waters, soils/sediments, and miscellaneous other samples (vegetation, air, filters, and sludges). These samples were analyzed according to protocols described in the U.S. EPA Contract Laboratory Program (CLP) Statements of Work, the methods described in "Test Methods for Evaluating Solid Waste" (EPA Document SW-846, U.S. EPA Office of Solid Waste and Emergency Response, Washington, DC, November 1986), or other appropriate procedures. Approximately 200 analyses were completed in FY 1993, including determination of inorganic constituents (metals, anions, cyanide, sulfide, and total dissolved and suspended solids), organic compounds (volatiles, semivolatiles, polychlorinated biphenyls/pesticides, phenolics, and oil and grease), and radionuclides (gamma emitters and actinides).

Orphan Waste Work Projects (D. G. Graczyk, A. M. Essling, I. M. Fox, D. R. Huff, E. A. Huff, F. P. Smith, C. T. Snyder, R. W. Bane, K. J. Jensen, L. E. Ross, D. L. Bowers, F. Markun, C. S. Sabau, L. L. Smith, B. S. Tani, T. TenKate, J. S. Yaeger, R. R. Heinrich, A. S. Boparai, D. V. Applegate, L. L. Chromizky, S. D. Kent, K. J. Parish, Y. Tsai, M. A. Gritters, S. M. Macha, P. C. Lindahl, J. J. Marr, and L. B. TenKate)

Many ANL facilities have waste materials left behind by programs that are no longer funded or materials whose origin is unknown or inadequately documented. Funding made available through ANL's Environment and Waste Management (EWM) Program has provided many of these facilities the opportunity to undertake work projects directed at accumulation, characterization, and documentation of these so-called "Orphan Wastes" so they may be properly disposed of. In support of a number of these work projects, the $\mathrm{ACL}$ is conducting chemical and radiological analyses to provide the composition and hazards-classification data needed by treatment/storage/disposal (TSD) facilities that will ultimately process the wastes. Working closely with the EWM Program to ensure that information and procedural requirements of the appropriate TSD facility are satisfied, ACL staff 
have prepared detailed sampling and analysis plans for some projects, have fielded sampling teams to collect appropriate representative samples, and have collaborated with EWM staff in interpreting the analysis results for waste handling.

Wastes characterized by the ACL this fiscal year have included several hundred gallons of preserved animal carcasses archived from radiological testing in the now-disbanded Biology Division (this work is described more fully in a separate section of the present report), several thousand gallons of lithium hydroxide solution from a collimator system in the ANL Fast Neutron Generator Facility, and hundreds of smaller waste items from various laboratories and storage areas. Many of these small items were unlabeled containers of solids, aqueous or organic liquids, and oils or sludges. When the material in these containers appeared to be pure chemical compounds or simple mixtures, we pursued an analytical approach that would provide a direct identification of the material and then relied on a Material Safety Data Sheet to obtain pertinent hazards information. For solids, X-ray fluorescence and X-ray diffraction analysis often gave the necessary information; for liquids and oils, several techniques (such as GC/MS and FTIR spectroscopy) were often employed. However, many wastes either could not be identified or contained complex mixtures of components; such wastes were evaluated for the Resource Conservation and Recovery Act (RCRA) characteristics of ignitability, corrosivity, toxicity, and reactivity. Wastes from radiological controlled areas required determination of the identity and quantity of radionuclides that might be present; these wastes were measured by gamma spectrometry, gas proportional counting, liquid scintillation counting, and/or alpha pulse height analysis.

Development of the Integrated Performance Evaluation Program (P. C. Lindahl, W. E. Streets, D. A. Bass, J. J. Marr, K. J. Parish, and P. L. Johnson)

In collaboration with DOE's Radiological and Environmental Sciences Laboratory (RESL), the Environmental Measurements Laboratory (EML), and Electronics and Computing Technologies 
Division (R. Krol and A. E. Scandora), the ACL is developing and implementing a comprehensive Integrated Performance Evaluation Program (IPEP) for DOE's Office of Environmental Restoration and Waste Management (EM), Office of Technology Development, Laboratory Management Division (LMD), EM-563. The program is designed to provide information on the quality of radiological and non-radiological analytical data being produced by all laboratories on which DOE is relying for analysis of environmental restoration and waste management samples. The ACL, in collaboration with S. Hedayat (University of Illinois, Chicago), is assisting the two lead DOE laboratories in developing the program requirements and strategies for implementation, especially in the non-radiological portions of the program. The ACL is also developing the strategies for compiling and analyzing the performance evaluation (PE) results, and for monitoring to assure that needed corrective actions are taken.

As part of the broader activities of LMD, the ACL also participates in Future Analytical Support Team activities. This group provides advice and needed data to assist EM-563 in meeting its objective of ensuring that the required capacity and capabilities exist to provide the analytical support for EM Programs.

An Interagency Agreement (IAG) between ANL and Region $\mathrm{V}$ of the Environmental Protection Agency (EPA) was renewed for FY 1993. This IAG allows us to nominate laboratories performing analyses for EM into laboratory performance evaluation programs and to access information about these laboratories from the Water Supply (WS) and Water Pollution (WP) programs of the Environmental Monitoring Systems Laboratory, Cincinnati, OH. The IPEP has nominated two laboratories for the WP program. Historical and current data from these programs are now routinely transferred from the EPA data base at Research Triangle Park (North Carolina) to the data base at ANL. A draft format for reporting compiled results of the WP studies has been developed and submitted to EM-563 for review and comment. The format for the reports on WS studies is under 
development. Two draft reports on current WP studies have been produced and submitted to EM563.

Under another IAG, we have continued to receive information for DOE government-owned, contractor-operated (GOCO) participants in the quarterly CLP organic and inorganic PE programs from EMSL-Las Vegas (EMSL-LV). Six draft reports on these programs have been prepared and submitted to EM-563. A Standard Operating Procedure for production of these reports is under development. To improve data handling efficiency and accuracy, we are establishing means to access electronic information from the CLP and the EMSL-LV Radiological Intercomparison Studies.

Data from the EML Quality Assurance Program (QAP) are being used to develop a performance-based statistical assessment and scoring scheme to meet EM-563 needs for use of this information. A report on these statistical tools was presented to an EM-563 QA Working Group in April 1993. The effects of small-participation cells and varying analyte concentration levels within the EML QAP were studied. Individual laboratory performance was assessed using these statistical tools.

The IPEP is one facet of the program by EM-563 to improve the quality of analytical data. Another facet is laboratory audits to identify and correct weaknesses in the process of generating data. In February 1993, EM-563 conducted a pilot laboratory audit of ACL as a training exercise for their personnel and as test of their audit materials. The ACL staff provided comments to the audit team and LMD on the conduct of the pilot audit for the purpose of strengthening the process.

In addition, the ACL also supported EM-563 efforts to develop the pilot studies for the Mixed Analyte Performance Evaluation Program, which was created to provide data not currently available in DOE and EPA performance evaluation programs. Data entry software was developed to allow participants to enter their results electronically into the IPEP data base. Analytical results have been received from all laboratory participants. We provided the statistical analysis of the data using the 
performance-based assessment tools being developed here. A draft report was prepared and presented to the EM-563 QA Working Group; preparation of the final report was begun.

Method Development for Waste Isolation Pilot Plant (A. S. Boparai, G. T. Reedy, D. V. Applegate, K. J. Parish, and S. D. Kent)

The Waste Isolation Pilot Plant (WIPP) in Carlsbad, New Mexico, has been selected as a possible permanent disposal site for transuranic radioactive wastes resulting from defense-related activities at DOE sites. The WIPP Program Plan calls for characterizing waste to be shipped to the site and evaluating, both experimentally and theoretically, the long-term consequences of burying waste at the site.

Wastes to be transported to the WIPP site must be characterized and shown to satisfy RCRA requirements, which limit the presence of hazardous compounds. One of the wastes to be shipped to the site is classified as "Type IV" organic waste sludge. The sludge, which results from the "solidification" of organic waste liquids by the addition of calcium silicate absorbent to immobilize the spent liquids, is present at the Rocky Flats site and elsewhere.

The ACL is involved with the development of analytical methods for the determination of polychlorinated biphenyls (PCBs) and hazardous semivolatile organic compounds (SVOCs) in the sludge. The method development for the determination of PCBs in the sludge is essentially complete. The method consists of extracting the PCBs from the sludge with solvent, cleaning the resulting extract with a polymeric absorbent to remove interfering compounds, and analyzing the extractant for PCBs using a gas chromatograph and electron capture detector.

Tests were conducted to show that ${ }^{239} \mathrm{Pu}$ is absent in the extract from the cleanup procedure. The method has been documented as an ACL technical report (K. J. Parish, D. V. Applegate, A. S. Boparai, and G. T. Reedy, "Determination of PCBs in Rocky Flats Type IV Waste Sludge by Gas 
Chromatography/Electron Capture Detection," Argonne National Laboratory Report ANL/ACL-93-1, 1993).

The analytical method being explored for use in determining SVOCs in the sludge also involves an extraction step. However, because the SVOCs targeted for detection are chemically similar to the organic compounds making up the bulk of the sludge, the cleanup step is more difficult. Several techniques are being tested for removing interfering compounds from the sludge extract. Effective cleanup of the extracts will allow the target SVOCs to be identified based on their GC retention times and mass spectra.

Determination of Low-Molecular-Weight Analytes in Waste-Drum Headspace Gas for WIPP Project (A. G. Engelkemeir, C. T. Snyder, and D. G. Graczyk)

Among the capabilities ACL has established for the WIPP Experimental Waste Characterization Program is a methodology for compositional analysis of waste-drum headspace samples to determine permanent gases and low-molecular-weight hydrocarbons (methane through propane). Volume-percent concentrations of each of ten target-analyte gases $\left(\mathrm{H}_{2}, \mathrm{~N}_{2}, \mathrm{O}_{2}, \mathrm{Ar}, \mathrm{CO}\right.$, $\mathrm{CO}_{2}, \mathrm{NO}_{x}, \mathrm{CH}_{4}, \mathrm{C}_{2} \mathrm{H}_{6}$, and $\mathrm{C}_{3} \mathrm{H}_{8}$ ) are measured with a magnetic-sector, gas-analysis mass spectrometer having moderate resolution. Instrument stability and sensitivity have been demonstrated to meet program requirements regarding precision, accuracy, and detection limits for measuring the gases of interest. Reliability of the instrument and procedures was reaffirmed during this past fiscal year by achieving passing scores on two Performance Demonstration Program sample sets (in October 1992 and July 1993). 
Determination of Volatile Organic Compounds in Headspace Gas for WIPP Project (D. V. Applegate, Y. Tsai, M. A. Gritters, G. T. Reedy, A. S. Boparai, and S. E. Carpenter)

In this project the ACL serves as one of the participating laboratories qualified to determine VOCs in the headspace of waste drums that will be shipped to the WIPP site for burial. The VOC analyses are based on GC/MS methods established by the ACL for analysis of 29 target compounds that are of particular interest to the WIPP project. Target compounds include aromatic hydrocarbons, chlorinated aliphatic hydrocarbons, diethylether, alcohols, and ketones. The ACL has been participating in the analysis of the WIPP performance demonstration samples and has successfully passed five cycles of analysis. We are now in the process of extending the current range of the calibration curve. The extended range will allow us to analyze WIPP samples over a wide range of analyte concentrations with fewer dilutions than are currently performed. This improvement in analytical techniques will lower analysis costs.

Holding Time Study of Volatile Organics in Canisters for WIPP Samples (G. T. Reedy, D. V. Applegate, M. A. Gritters, S. E. Carpenter, and A. S. Boparai)

As part of the WIPP Waste Characterization Program, headspace gas samples from waste containers are analyzed for a set of 29 volatile organic compounds that are required by the program. The selected analytes consist of the following classes of compounds: ethers, alcohols, ketones, aliphatic and aromatic hydrocarbons, and halogenated hydrocarbons. The headspace samples are collected in passivated SUMMA canisters with an allowable holding time of 28 days from the date of collection to date of analysis. Experiments are underway to determine how long the holding time could be extended for each of the target analytes.

The experimental data on holding times were not obtained using standards prepared in the laboratory because of the concern that the headspace samples collected from the WIPP waste containers might contain compounds other than the WIPP analytes that could affect the stability of 
the WIPP analytes. Therefore, two field samples were selected for the study. The samples had been analyzed within the 28-day holding time by Idaho National Engineering Laboratory and were later sent to ANL. One of the samples has been analyzed periodically over the last 4 months without addition of any other compounds. The second sample was spiked with eight WIPP analytes that have an occurrence frequency of $15 \%$ or higher. The reason for spiking the sample was that it allowed us a known reference point from which to measure the loss of analyte. Preliminary results from both samples indicate that the holding time could be extended well beyond the current 28 -day limit. One practical consequence of these results is that each batch may contain a larger number of samples without loss of accuracy, which would lead to more efficient and cost-effective analyses. The results of this study will be presented in a report that is in preparation.

\section{Robotic Extractions in a Glovebox (K. J. Parish, A. S. Boparai, and G. T. Reedy)}

The objective of this project is to install a robot to perform extractions on radioactive soils and sludges in a glovebox for subsequent determination of the semivolatile organic and PCB/pesticide constituents. The robot that was procured for this project was the Zymate XP robot supplied by Zymark Corporation (Hopkinton, Massachusetts).

The complete hardware was received and has been configured on an aluminum plate, which was cut to the dimensions of the floor of the glovebox. The robot will first be tested with nonradioactive samples outside of the glovebox, but within the confines of the glovebox dimensions. The robot has been programmed to perform two different extraction procedures. One procedure is the extraction of PCBs from Rocky Flats Type IV waste sludge, which must be analyzed as part of the WIPP program. This procedure has been partially checked for proper operation and valid results; however, some problems in the procedure remain to be resolved. The other procedure is for the extraction of semivolatile organic compounds from soils and sludges. This procedure must still be 
checked for proper operation and valid results. Once the proper qualifications of the machine and validation of the methods have been demonstrated, the robot will be ready for use in the glovebox environment. The glovebox is currently being prepared to accommodate testing of the robot.

Support for High-Temperature Superconductor Development (A. M. Essling, E. A. Huff, D. R. Huff, F. P. Smith, I. M. Fox, B. S. Tani, K. J. Jensen, and D. G. Graczyk)

The ACL continued providing extensive analytical support to high-temperature superconductivity programs in the Energy Technology and Chemical Technology Divisions. Much of this work involves analysis of starting materials, process samples, and products related to fabrication and characterization studies on various ceramic compositions, including $\mathrm{YBa}_{2} \mathrm{Cu}_{3} \mathrm{O}_{7-\mathrm{x}}$ ("123-compound") and newer ceramics such as lead-doped bismuth/strontium/calcium/copper oxides ("BSCCO" ceramics). Our measurements include determining elemental composition by ICP/AES or classical methods, anions by ion chromatography, carbon with a LECO analyzer, and phase composition by X-ray powder diffraction. We also use an iodometric titration method to determine excess valence of the metals in a given ceramic (e.g., $\mathrm{Cu}^{3+}$ ), which is related to the oxygen stoichiometry of the compound.

This past year, interest of researchers has shifted from study of the 123-compound to the BSCCO ceramics, which exhibit several superconducting phase compositions [e.g., the 2212 phase, $(\mathrm{Bi}, \mathrm{Pb})_{2} \mathrm{Sr}_{2} \mathrm{CaCu}_{2} \mathrm{O}_{\mathrm{x}}$; the 2223 phase, $\left.(\mathrm{Bi}, \mathrm{Pb})_{2} \mathrm{Sr}_{2} \mathrm{Ca}_{2} \mathrm{Cu}_{3} \mathrm{O}_{\mathrm{x}}\right]$. Researchers at $\mathrm{ANL}$, often in collaboration with scientists at universities and commercial organizations, are investigating new ways to prepare the BSCCO ceramics and are studying the chemical and physical properties of the specimens they obtain. New analytical challenges have arisen from these studies. In one case, we were asked to determine the metal content of viscous, organic-acid solutions used as starting material in a new approach to making BSCCO ceramics. Providing the needed data required development of a special microwave-assisted digestion procedure to destroy the organic phase and produce sample 
solutions compatible with measurements by ICP/AES. We have also established a closed-vessel aciddissolution procedure to dissolve virtually any BSCCO material for compositional analysis. In general, the BSCCO system exhibits potential for forming mixed phases and has a more complicated chemistry than the 123-compound. Compositional changes can arise from variations in metal stoichiometry (e.g., non-integer stoichiometry numbers for one or more metals) as well as from variations in the valence of $\mathrm{Pb}, \mathrm{Bi}$, or $\mathrm{Cu}$. This range of compositional variation in the $\mathrm{BSCCO}$ materials makes chemical analysis of individual specimens very important to understanding and comparing results. Our experience with these materials suggests that more precise methodology is needed for their compositional analysis, as well as new approaches to characterize the metal valences that occur in them. The ACL plans to pursue development of capabilities to satisfy these needs.

Methodology for Characterizing Chlorofluorocarbons in Polyurethane Foam (A. G. Engelkemeir, A. M. Essling, F. P. Smith, C. T. Snyder, and D. G. Graczyk)

Researchers in the Energy Systems Division (D. Karvelas and P. Bonsignore) are collaborating with the U.S. Bureau of Mines and the Appliance Recycling Centers of America in a study to characterize chlorofluorocarbons (CFC) present in the polyurethane foam insulation from discarded appliances, such as refrigerators and freezers. The information from this study is intended to aid development of technology to recover CFC from discarded foam as part of a worldwide effort to reduce $\mathrm{CFC}$ emissions to the atmosphere and prevent CFC destruction of the earth's ozone layer. There is more $\mathrm{CFC}$ as insulating gas in the polyurethane foam of a typical refrigerated appliance (680 to $1530 \mathrm{~g}$ ) than is present as refrigerant in the appliance cooling system (170 to $340 \mathrm{~g}$ ). The ACL was asked to investigate methods for determining the CFC content of representative foams for this research. To determine the total CFC content of a foam sample, we applied a method that involved combustion of the foam sample under high-pressure (2.5 MPa) oxygen followed by ionchromatographic measurement of the chloride and fluoride products of the CFC combustion. We also 
devised a method for releasing CFC from the foam cells by cooling the foam to liquid nitrogen temperature in a closed vessel and pulverizing the embrittled foam to destroy the cell structure. Mass spectrometric examination of gas released during pulverization of the foams showed the gas to contain $>99 \% \mathrm{CFCl}_{3}$ ("CFC-11"), which is a common blowing agent and insulating gas for polyurethane foams. From oxygen-bomb combustion of the pulverized foam residue, we determined that only about 60 to $80 \%$ of the chlorine and fluorine in the original foam could be released by breaking up the foam structure. This result might be explained by CFC permeation into the solid foam matrix. This condition would make it difficult to recover CFC by the foam-maceration technologies currently in use by the recycling industry.

Studies of TRU $\cdot$ Spec and RE-Spec Chromatography (E. A. Huff and D. R. Huff)

The Separations Group (E. Horwitz et al.) in ANL's Chemistry Division has developed unique column extraction phases that have applications in environmental and bioassay areas. These materials (TRU•Spec and RE•Spec) are now commercially available (Eichrome Industries, Inc.). However, only a limited amount of information on their properties has been published. In FY 1993, we completed a comprehensive survey of distribution coefficients $\left(K_{d}{ }^{\prime} s\right)$ for the TRU $\bullet S p e c$ and RE•Spec extraction phases as a function of mobile phase composition for 30 elements. Column elution experiments were used to generate a $K_{d}$ data base for these extraction phases in hydrochloric and nitric acid systems. Distribution coefficients for the 30 elements were determined from ICP/AES measurements. The results of this study indicate that, by proper choice of the mobile phase, group separations (e.g., rare earths, actinides) can be achieved, thus simplifying analytical determinations and facilitating data interpretation. This approach has been applied to analysis of extracts from simulated nuclear fuel standards, nuclear waste glasses, and environmental samples. Availability of the $\mathrm{K}_{\mathrm{d}}$ data allowed design of selective separation schemes for application to many different matrix 
compositions and greatly simplified the task of choosing the best column/mobile-phase combination for each application.

Analysis of Simulated Nuclear Waste Glasses and Slags (A. M. Essling, D. R. Huff, E. A. Huff, F. P. Smith, I. M. Fox, and D. G. Graczyk)

The production of stable nuclear waste forms and their long-term storage in nuclear repositories are of great importance to nuclear power production and to DOE's environmental restoration and waste management activities. The Unsaturated Glass Testing Program at CMT (J. Bates, J. Mazer, X. Feng, et al.) has the objective of evaluating factors that are likely to affect glass reactions in an unsaturated environment typical of a candidate repository site such as that at Yucca Mountain, Nevada. The ACL has established a variety of dissolution and analysis methods tailored to the challenging task of determining the composition of materials classified as glasses and slags. These methods were put to use during the past year in characterizing Minimum Additive Waste Stabilization (MAWS) samples, which included synthetic slags containing high levels (up to 22 wt $\%$ ) of iron and glasses that were high (about 12\%) in fluorine content. Closed-vessel decomposition with mixed mineral acids (usually nitric and hydrofluoric acids) is usually most effective for dissolving these materials; we use both Parr bombs and microwave-heated digestion vessels for this application. The solutions obtained are subsequently analyzed by ICP/AES to determine component elements.

Some of ACL's methodology for analyzing glasses was also applied to a Waste Glass Analytical Round Robin (Round Robin 7) administered by the Materials Characterization Center at Pacific Northwest Laboratory. With support from the Glass Testing Program in CMT, the ACL prepared two unknown glasses and a glass standard in duplicate and analyzed each solution by ICP/AES for 20 elements on each of three days. Ferrous iron in each of the glasses was determined by a modified Pratt titration. All the results we obtained compared favorably with the accepted compositional data provided for the Round Robin by Corning, Inc. Both the component 
concentrations measured by ICP/AES and the ferrous/ferric iron ratios we reported were within measurement uncertainties of the reference values. These results confirmed satisfactory performance of our methods and help corroborate data we provide to ANL programs for similar materials.

Characterization of Used Filters for Disposal (A. M. Essling, F. P. Smith, I. M. Fox, A. T. Sherren, E. A. Huff, D. R. Huff, S. D. Kent, K. J. Parish, Y. Tsai, L. L. Chromizky, M. A. Gritters, L. B. TenKate, T. TenKate, L. L. Smith, D. L. Bowers, A. S. Boparai, and D. G. Graczyk)

High-efficiency particulate-air (HEPA) filters provide the final stage of containment on many laboratory exhaust systems in ANL facilities by preventing escape of chemical and radioactive materials entrained in the exhausted air. For a number of years, used HEPA filters removed from these systems have accumulated in ANL's EWM Waste Management Department (EWM-WM) because no facility could be found that would accept them for disposal. Recently, EWM-WM determined that these used filters would be accepted for disposal at DOE's Hanford Reservation if they could be shown to meet the relevant Hanford waste acceptance criteria. Procedures were proposed in EWM-WM for repackaging and composite sampling of the used HEPA filters, and ACL was asked to establish analysis methodology for evaluating the composite samples against the Hanford criteria.

By working with material from an unused HEPA filter, we tested methods for homogenizing the pieces of filter in the composite sample generated during the EWM-WM repackaging process and for analyzing the homogenized composite. Homogenizing the composite sample proved to be quite difficult because of the fibrous, fabric-like nature of the HEPA filter media. We ultimately settled on a process wherein the filter material was manually cut (with scissors or a small paper cutter) into small pieces (approximately $5 \times 5 \mathrm{~mm}$ ), which could be mixed and subsampled in a controlled manner. For containment during the cutting process, the manual operations were performed in a closed glovebox in a laboratory fume hood. 
Once a uniform composite sample was prepared, we tested procedures for determining specific contaminants in the HEPA filter media. These included procedures for evaluating $\mathrm{pH}$, metal content, inorganic anions, sulfide and cyanide, semivolatile organic compounds, PCBs, and radionuclides. All the tested procedures were applied to a sample of used HEPA filter with satisfying results. Results from duplicate portions of the homogenized composite agreed within normal method precision and demonstrated that the composite material was uniform. Westinghouse Hanford has given preliminary concurrence that the ANL characterization of these filters will satisfy their criteria for accepting them as low-level radioactive waste. On this basis, EWM-WM has initiated a campaign for FY 1994 that will generate almost 100 HEPA filter composite samples for analysis. If successful, this campaign will provide a major reduction of the historical waste inventory at the ANL site.

Stand-off Detection (J. C. Demirgian and S. M. Macha)

The U.S. Army's Chemical Research, Development and Engineering Center (now the Edgewood Research, Development and Engineering Center) has an ongoing program in stand-off detection of chemical plumes. The objective of this project is to support their effort by testing instrumentation. This testing includes determining the sensitivity of newly designed passive-remote FTIR spectrometers and enhancing the ability of existing spectrometers to properly detect plumes in the presence of interferences.

Our research was first focused on testing the ability of FTIR spectrometry to differentiate a single agent in a complex mixture of components that have interfering spectral absorbances. The results showed that detection can be accomplished in the spectral domain even on these difficult mixtures. We found that partial least square methods are more appropriate than classical least square methods for detection under these circumstances. A complete data set was delivered to the U.S. Army. 
We are currently building an analyte data base consisting of quantitative data at different black-body temperatures. Several analytes will be investigated. We will use this data set to determine the ability of the FTIR instrumentation to detect analytes under differing background conditions. The black-body emission spectra will be correlated with different field-emission data.

Characterization of Products and Residues from Automobile Shredder "Fluff" Recycling (A. M. Essling, F. P. Smith, I. M. Fox, A. T. Sherren, L. B. TenKate, E. A. Huff, D. R. Huff, K. J. Jensen, R. W. Bane, L. L. Chromizky, K. J. Parish, S. D. Kent, Y. Tsai, D. G. Graczyk, C. T. Snyder, S. E. Carpenter, and A. S. Boparai)

About $225 \mathrm{~kg}(25 \%)$ of every junked car that is processed by automobile shredders to recover ferrous-metal scrap is made up of a mixture of plastics, glass, fibers, and foam. This mixture is referred to as "fluff" and represents a substantial waste side stream from the automobile shredder industry. At present, shredder fluff is sent to landfills. Researchers in the Energy Systems (ES) Division (E. Daniels et al.) have developed and are testing technologies to segregate and recover the plastic and foam fluff components for recycling and are exploring alternatives to landfill disposal for residues ("fines") that are collected during segregation of the recyclable materials. The ACL is providing chemical analyses to help characterize the various product streams from these processes, including oils, recovered plastics and foams, and the shredder fines. An FTIR microscope is used to examine plastics recovered by solvent extraction of shredder residues. Here, selectivity of the extraction and purity of the products are assessed by comparing spectra from polyvinylchloride and acrilonitrilebutadienestyrene standards to spectra from reconstituted plastics from the process. Other analysis methods are applied to determine specific contaminants in the foams, oils, and fines. Heavy metals and PCBs are common contaminants in the shredder fluff as a result of their presence in automotive components and fluids (e.g., lead from batteries, mercury from mercury switches, PCB from capacitors or hydraulic fluids). After suitable treatment of samples to bring the metals into solution, they are analyzed by ICP/AES or cold vapor atomic absorption spectrophotometry. The 
PCBs are extracted with an appropriate solvent and measured by gas chromatography. We also determine the total chlorine content of many samples by a procedure that employs oxygen-bomb combustion and ion chromatography to measure the chlorine as chloride.

These and other analysis tools were used during the past year to provide the ES Division with (1) data on the effectiveness of a new process to remove metals and oil contaminants from polyurethane foams from the shredder fluff and (2) a comprehensive characterization of shredder fines to determine their suitability for disposal by incineration in a cement kiln.

Analysis of Environmental Samples for the U.S. Department of Agriculture (L. L. Chromizky)

Over the past five years, the ACL has participated in a collaborative effort with the Environmental Research Division (M. C. Hansen) that involves monitoring removal of contaminants (carbon tetrachloride and chloroform) from groundwater under a former grain storage facility in Waverly, Nebraska, operated by the U.S. Department of Agriculture. Contaminants from the Waverly aquifier are being removed by groundwater extraction and air stripping. By the end of FY 1993, carbon tetrachloride contamination in the Waverly aquifer remained at the same concentration as was measured at the end of FY $1992(\sim 47 \mathrm{ppb})$.

The aquifer will continue to be sampled monthly in FY 1994 because the concentration of carbon tetrachloride is above the Federal health standard of $5 \mathrm{ppb}$. Samples received in August 1993 included an aliquot from a well in a plume outside of the current extraction area. Because the sample contained a carbon tetrachloride concentration of $40 \mathrm{ppb}$, samples from three additional monitoring wells will be submitted monthly beginning in October 1993. In FY 1993 the ACL analyzed over 50 groundwater and drinking water samples for this project. 
Radiochemical Method Evaluation and New Method Development (J. S. Crain, P. C. Lindahl, and L. L. Smith)

Estimates by the DOE suggest that 1.4 million radiochemical analyses or more will be required annually to support environmental restoration and waste management activities. The cost and turnaround time of these analyses could be reduced substantially by streamlining current radioanalytical procedures. The ACL and Environmental Research Division staff (led by $\mathrm{M}$. Erickson) are examining existing radiochemical procedures and formulating research and/or subcontracting plans to develop new techniques for sample preparation and measurement.

As part of this program, ACL staff reviewed existing radiochemical procedures and recommended areas for improvement; the ACL recommendations were affirmed and strengthened by an expert working group convened by DOE/EM-563. From that point, strategies were developed to facilitate improvements in sample preparation and analysis. As part of that strategy, specifications were developed for subcontract procurement of automated gross alpha/beta emitter determination and automated soil dissolution; in addition, work plans were formulated for developing improved actinide isolation procedures and determining radioisotopes by ICP/MS. Both projects will continue in FY 1994 with emphasis on demonstration and automation.

\section{Automated, Real-Time Analysis of Chemical Sensor Data (S. E. Carpenter)}

In any environmental monitoring situation, "instantaneous" detection of target analyte is the ultimate goal. The need for rapid data collection, analysis, and accurate evaluation is increasingly apparent whether the analyte is a toxic gas or an impurity in a process stream, nor does it matter whether the detection is accomplished by spectroscopic, electrochemical, or chromatographic techniques. In modern instrumentation, the initial step in automated data processing has already been taken, namely, computer-controlled data collection. However, many computer-controlled analyses quickly generate a plethora of data, often requiring further mathematical treatment to be useful. 
Therefore, data are commonly stored for subsequent expert analysis. Unfortunately, this sequence is counter productive to the goal of "instantaneous" (real-time) detection.

Real-time analyte measurements must be performed by a sensor that includes the data analysis and evaluation steps. Such sensors must employ a signal processing strategy that is able to (1) extract analyte information from background noise and interferences and (2) make an immediate decision regarding the presence or absence of analyte information.

The goal of real-time signal processing can be accomplished using digital filters. A digital filter is mathematically calculated and is described by a frequency response function. This function is defined by the analyst and is tailored for a particular target compound. Different compounds of interest require separate digital filters. A digital filter extracts and enhances the analyte signal by suppressing unwanted signal components due to other sources, resulting in improved detection limits and fewer interferences from other compounds. Customized digital filters are often computed before real-time analysis by using a controlled set of data. Application of digital filters in real time requires a minimal number of computations and is very rapid.

Because filtered data containing analyte information are visually different from filtered data containing no analyte information, standard pattern recognition (PR) techniques can be used to make an automated decision regarding the presence or absence of target analyte information. Mathematically, filtered data are treated as a vector (or pattern) in a hyperspace in which it is possible to distinguish among known pattern classes. Techniques such as discriminant analysis can then be used to construct a separating boundary (discriminant) between pattern classes. Automated classification of new patterns is achieved by comparing them to the discriminant. As with digital filters, a separate discriminant is required to identify each compound of interest. The number of computations required to perform PR during a series of measurements is minimal because 
discriminants are also computed before data collection and analysis by using a controlled set of data. Therefore, PR accomplishes the second objective of real-time signal processing.

Current work in the ACL includes designing and applying unique computer software for creating real-time signal processing algorithms for chemical sensors of interest to the Arms Control and Nonproliferation Program. The software integrates digital filtering and PR techniques and has been implemented on a Silicon Graphics (Mountain View, CA) Indigo workstation. The computational power of a workstation is optimal for manipulating large quantities of data, performing the extensive calculations required to construct customized digital filters, and developing reliable pattern discriminants. The capabilities and general utility of the software are being evaluated using data collected by a passive FTIR remote sensor.

\section{X-ray Diffraction Analyses (B. S. Tani)}

The ACL's X-ray diffraction (XRD) analysis has assisted research in several ANL programs during FY 1993, including high-temperature superconductivity, IFR, orphan waste, advanced battery, and fuel cell programs. To optimize fabrication of superconductive tapes, experiments were conducted by J. S. Luo and N. Merchant (CMT), who varied parameters such as temperature, starting material composition, atmosphere, and pressure. Analysis of each sample by metallography, transmission electron microscopy (TEM), SEM, and XRD produced information with which we determined the region of most favorable superconductive tape formation. The XRD technique was used to monitor phase formation, orientation of the phases, and crystallinity, which are important factors in suitable tape formation.

The XRD technique has assisted in failure analysis of components in electrochemical cells. Poor cell performance can be associated with unwanted migration of materials and change in 
properties of the separator and interconnect. We used this method for examining phase changes before and after cell operation to determine component integrity and the extent of cell degradation.

In FY 1993, many orphan waste samples were screened by XRD and X-ray fluorescence. The data obtained were useful in evaluating the need for additional analyses required to determine the appropriate disposal mode.

Analysis of Coal Byproducts (E. Y. Hwang, S. D. Kent, E. Vinokour, and A. S. Boparai)

The objective of this project is to determine the organic constituents of coal combustion byproducts and coal waste samples by applying traditional and advanced organic analytical techniques. Analysis of fly-ash samples is especially important in view of the large amount of fly ash from coal combustion that needs to be stored. Currently, we are analyzing ash samples for the presence of polynuclear aromatic hydrocarbons $(\mathrm{PAH})$ by solvent extraction. We are also planning to perform supercritical fluid extraction of the same samples and compare the recovery of PAHs by these two methods. The ash samples are also being analyzed for certain inorganic constituents.

\section{Treatment of Cesium-Contaminated Milk (J. S. Crain and L. B. TenKate)}

In the Ukraine, a million gallons of milk is destroyed each day as a consequence of contamination by radioactive cesium and strontium. In 1993, Argonne staff, led by D. Johnson (Energy Systems Division), conducted tests with Bradtec Ltd. (Bristol, UK) to demonstrate that its $\mathrm{MAG}^{*} \mathrm{SEP}^{\circledast}$ process (which uses specially coated magnetic particles to absorb heavy metals and radioactive contaminants from solution) could be used to reduce the cesium concentration in milk to acceptable levels.

Two separate tests were conducted during this demonstration. In a laboratory-scale test

performed by K. Orlandini (Environmental Research Division), $65 \mathrm{pCi} / \mathrm{g}$ of ${ }^{137} \mathrm{Cs}$ and $2 \mathrm{mg} / \mathrm{L}$ of 
natural cesium were added to one liter of milk prior to treatment. After four contacts with $\mathrm{MAG}^{*} \mathrm{SEP}^{\circledR}$, the ${ }^{137} \mathrm{Cs}$ activity was reduced to $4 \mathrm{pCi} / \mathrm{g}$, which is 2.5 times less than the prescribed intervention level. In a second test coordinated by $\mathrm{C}$. Negri (ES), $2 \mathrm{mg} / \mathrm{L}$ of natural cesium was added to $57 \mathrm{~L}$ (15 gal) of milk prior to $\mathrm{MAG}^{*} \mathrm{SEP}^{\circledR}$ treatment in a pilot-scale facility. The ACL staff were asked to determine the cesium content in the pilot-plant feedstock and effluent (i.e., contaminated and treated milk, respectively).

The method of standard additions was selected for these determinations because it is relatively insensitive to matrix-related interferences. Cesium (analyte) and indium (internal standard) spikes were added to the sample aliquots before any preparative chemistry was performed to compensate for analyte losses during preparation. Samples were then treated using Method 16.047 ("Official Methods of Analysis of the Association of Official Analytical Chemists," Ed., Kenneth Helrich, 15th ed., AOAC, Arlington, VA, 1990) to remove suspended solids and proteins from the milk prior to instrumental analysis. Once the AOAC method was completed, ICP/MS was used to determine the cesium content of the supernatant liquid.

The cesium detection limit for the AOAC method was found to be $2 \mathrm{ng} / \mathrm{mL}$. The "measured" and "prepared" concentration of cesium in the untreated milk agreed to within $10 \%$ (i.e., one standard deviation of the instrumental measurement), and the cesium content of the treated milk indicated that $78 \%$ of the cesium was removed by a single contact with $\mathrm{MAG}^{*} \mathrm{SEP}^{\circledR}$ particles. This result did not agree with the laboratory-scale test, where $50 \%$ of the cesium had been removed per contact. It was later found that the milk in the pilot-scale study had been inadvertently diluted by water in the process lines. Dilution reduced the cesium concentration in the process effluent, thereby increasing the apparent decontamination factor. With this correction taken into account, reasonable agreement was obtained between our results and the laboratory-scale test. Further refinement of the pilot-scale process will be needed before the decontamination procedure can be used commercially. 
Analysis of Organic Mixed Waste (S. D. Kent, L. L. Chromizky, K. J. Parish, Y. Tsai, D. V. Applegate, E. Y. Hwang, and A. S. Boparai)

The ACL has established capabilities for analysis of VOCs, SVOCs, and PCBs/pesticides in radioactive samples. Standard operating procedures have been written for organic analysis of mixed waste samples based on protocols given in the EPA Contract Laboratory Program and the RCRA (EPA SW-846) methods. Currently, we are analyzing mixed waste samples for VOCs, SVOCs, and PCB/pesticides required by the CLP and RCRA programs.

The solid matrices analyzed have included evaporator still-bottom residue adsorbed on vermiculite, sludge, and soil samples; the aqueous samples have included concentrated nitric acid solutions, water containing an oil layer, and groundwater samples. All samples analyzed have activity levels below the limits specified in the safety analysis for this facility below $(40 \mathrm{mR} / \mathrm{h}$ at $5 \mathrm{~cm})$ and within the alpha and beta/gamma specific radioactivity limits.

\section{Analysis of Explosives Residues (S. D. Kent)}

Soil samples were submitted to the ACL from the Environmental Research Division (R. Boopathy) for analysis by liquid chromatography/mass spectrometry as part of a study to explain the bioremediation of trinitrotoluene (TNT) in a slurry reactor. The ACL identified two unknown intermediates of trinitrobenzene (TNB) that were detected in previous work using high pressure liquid chromatography.

The instrumentation used for the work consisted of a Hewlett Packard 5989 mass spectrometer interfaced with an HP 1090 liquid chromatograph with photodiode array detection. The particle beam/generator interface was used in this study, and the mass spectrometer was operated in both the scan and selection modes.

The data were initially obtained using the LC/MS particle beam for low concentrations of TNB (50 ppm), and identification of the corresponding intermediates was inconclusive, because the 
analyte was typically removed with the solvent mobile phase in the beam/generator interface. As larger concentrations of TNB standard $(71,000 \mathrm{ppm})$ were injected into the LC/MS, enough analyte reached the ionization chamber of the mass spectrometer to allow identification.

Later work revealed that a thermospray interface with a softer ionization technique could be used to detect TNB at low concentrations. The spectra obtained using thermospray differ from those obtained with traditional electron impact; however, the molecular ion is clearly visible in thermospray spectra for qualitative analysis.

Calcium Isotopic Determination in Canine Bone and Blood Serum (J. S. Crain, A. T. Sherren, and E. A. Huff)

Biological and Medical Research Division staff (led by M. Bhattacharyya) are studying the effect of cadmium exposure and ovary removal on metabolic uptake and incorporation of calcium into bone. The protocol for their study involved administering oral and intravenous doses of enriched calcium isotopes to canine subjects and then withdrawing serum and bone samples from the subjects at an appropriate interval after the dose was administered. The relative abundances of the calcium isotopes in these samples indicate the extent of uptake and incorporation.

The ACL is using ICP/MS to measure the extent of isotopic depletion or enrichment in the samples. The samples were ashed and reconstituted in nitric acid such that the total calcium concentration was approximately $10 \mathrm{mg} / \mathrm{L}$, which minimizes spectral interferences inherent at the mass-to-charge ratios of interest. The isotope ratios in the samples were measured relative to a control sample (i.e., a bone or serum sample that was unspiked) in an effort to closely match the sample matrix to a standard of known (natural) isotopic composition. The isotope ratios were typically measured with an internal precision of $\pm 0.2 \%$ relative standard deviation.

Isotopic analysis of 24 bone samples indicated no clear departure in bone from the natural calcium isotopic distribution. Agreement between duplicates was generally within expected 
uncertainties. Isotopic analysis of eight serum samples (without duplicates) indicated a significant departure from the natural calcium isotopic abundance. Because bones are an extremely large calcium reservoir, it is unlikely that the expected isotopic perturbations in bone could be detected. Thus, determination of metabolic calcium uptake will be based on our isotopic analysis of the serum samples.

Computer Generation of Reporting Forms for Environmental Analysis (Y. Tsai and L. L. Chromizky)

Numerous environmental samples received by the ACL require reporting results on forms specified by the EPA Contract Laboratory Program (CLP). In the past, calculations were done by the analyst, and several forms were filled out manually. We have installed ENVISION software (developed by THRU PUT System, Inc.) on a Hewlett Packard UNIX ChemSystem to automate the process of generating final and quality control reports from analyses of soil and water samples to determine VOCs, SVOCs, and PCB/pesticides. Analytical data files can be easily transferred into a data base and processed by ENVISION to generate CLP reporting forms. In addition to ENVISION, the TARGET software which provides target compound analysis for GC/MS, can also automatically generate CLP-type format reporting forms for SW-846 methods. By computer generation of the forms, a significant time savings has been realized.

\section{Battery Program (J. J. Marr)}

In FY 1993, the ACL continued to provide technical support to the CMT Battery Program in the area of post-test analysis of nickel/metal hydride cells. The objectives of the post-test analysis are to understand the failure mechanisms of the nickel/metal hydride cells and to help in the design of cells with longer cycle life and better performance. 
During the past year, ACL staff assisted in developing a procedure for the post-test analysis of nickel/metal hydride cells and examining failed cells to identify the existing and potential modes of failure. More than 20 cells were examined. All of the cells were obtained from Ovonic Battery Company and tested at the CMT Analysis and Diagnostics Laboratory under an electric vehicle testing regimen until they failed to meet performance standards. After failure, cells were opened and examined for such factors as changes in the dimensions and composition of the electrodes, distribution of the electrolyte, and physical condition of the separators. The data obtained from these detailed examinations were evaluated. This data evaluation permits accurate assessment of the technical progress in battery research and indicates needed design and/or material changes. Results of the analyses have been documented and forwarded to the battery developer and to program personnel for review.

Technical Support to DOE-CH (C. T. Snyder, P. C. Lindahl, R. R. Heinrich, D. L. Bowers, and D. W. Green)

Several members of the ACL staff provided technical support to the Research and Development Laboratory Working Group (RADWG) DOE-Chicago Operations Office. The RADWG was formed in March 1991 and initially consisted of a small group of representatives from R\&D laboratories (under the jurisdiction of DOE-CH). These representatives were assembled to discuss the waste shipping moratorium and the waste characterization tasks associated with assessing the requirement of "no DOE-added radioactivity." Over the course of the next two years, the RADWG grew to include many interested parties from inside and outside the DOE community, as well as representatives from DOE-HQ. Input from committee members allowed the group to produce several guidance documents for DOE as part of an effort to provide a uniform approach to addressing the characterization tasks associated with the waste shipping moratorium. This characterization will use methods currently in use at the laboratories. 
D. Green, P. Lindahl, and C. Snyder are members of the RADWG Analytical Chemistry Laboratory Committee (ACLC) and worked on the document "Recommendation for Analysis for Bulk Radioactive Contamination." They also served on the Interlaboratory Analytical Capabilities Committees (IACC), which produced and circulated a survey among RADWG organizations polling them on their analytical laboratory capabilities and their environmental restoration and waste management projects' analytical needs. P. Lindahl serves as the Chairman of the IACC. In addition, C. Snyder and D. Bowers are members of the Release Criteria Committee, which drafted the document "Recommendations for Analytical Sensitivity Required to Determine the Presence of DOEAdded Radioactivity in Hazardous Wastes."

\section{Advanced Photon Source Thrust Group (W. E. Streets and B. S. Tani)}

This intradivisional group was founded in January 1989 to explore possible interactions between CMT with the Advanced Photon Source (APS) for current and future research programs. The group was directed (1) to gather and disseminate information on the application of synchrotron radiation (SR) in research areas of interest to CMT; (2) to familiarize CMT staff with the capabilities, procedures, nuances, and costs associated with research at the APS; (3) to arrange seminars on the use of synchrotrons in research areas germane to CMT; and (4) to create a link with the other divisional synchrotron thrust groups at ANL. The eventual goal of the group is to develop a plan for utilization of the APS by CMT. As specific interests within the division for use of SR have become better defined, it was decided that the Thrust Group should be reorganized to better represent those interests. The group now consists of the following CMT members: D. Chaiko, R. Chiarello, P. Finn, C. Johnson, L. Leibowitz, M. Lewis, V. Maroni, E. Streets (Chairman), W. Swift, S.-W. Tam, and D. Zurawski. 
The Thrust Group has continued to investigate ways that CMT as a division might participate in research at APS. Contact has been made with three APS Collaborative Access Teams (CATs) to investigate the possibility and feasibility of joining their efforts. The Thrust Group has developed criteria for our collaborative efforts on these teams and formalized them in an initial contact letter. Contacts with the identified CATs are continuing.

Upon the advice of the Thrust Group, CMT has continued its support of Dr. K. D'Amico, a consultant in SR research who has worked for the previous two years with CMT personnel. Dr. D'Amico has advised and assisted various CMT groups on SR questions and issues. He has also functioned as an advisor to the Thrust Group in its investigation and identification of potential CMT partners at APS.

Workshop on Hyphenated Techniques (A. S. Boparai, D. V. Applegate, G. T. Reedy, S. E. Carpenter, S. D. Kent, and M. Clapper-Gowdy)

In cooperation with the Division of Educational Programs, ACL staff helped present a two-day hands-on workshop for college faculty on combined analytical techniques. The workshop was entitled "Hyphenated Techniques in Analytical Chemistry: HPLC/MS (high performance liquid chromatography/mass spectrometry) and SFE/GC (supercritical fluid extraction/gas chromatography)" and was attended by eight professors from colleges in Illinois, Indiana, Wisconsin, Ohio, and Missouri. Staff from the ACL made presentations covering theory and applications of HPLC/MS and SFE/GC. The participants then did laboratory analyses using these instruments. The HPLC/MS experiments utilized the particle beam interface as a source, while SFE was performed in the off-line mode using carbon dioxide as the supercritical fluid. 
Analytical Chemistry Support for Emergency Response and Investigation (D. V. Applegate, A. S. Boparai, F. P. Smith, I. M. Fox, and D. G. Graczyk)

On May 26, 1993, an ANL employee was injured when he unknowingly mixed incompatible chemicals as he was consolidating waste solutions that were supposed to contain only nitric and hydrofluoric acid. As part of the emergency response to this occurrence and subsequent investigation into its cause, ACL provided timely chemical analysis information to determine the composition of the solutions that were involved. Samples of the solution that remained in the container that was directly involved in the occurrence were titrated to determine their acid content, analyzed by ion chromatography to identify the acids present, and examined by GC/MS to determine whether reactants were present that might pose a hazard to waste management (EWM-WM) personnel dealing with the cleanup of the reaction residue. The solution was determined to be a stable mixture of nitric, hydrofluoric, and acetic acids, although minute traces of ethanol and ethanol derivatives were tentatively identified. This information allowed the reacted waste to be put in a proper container and moved to safe storage. We also analyzed several waste solutions, previously generated in the same laboratory, which were packaged and stored in an EWM-WM facility pending shipment of the solutions for disposal. These were found to contain only nitric and hydrofluoric acids in proportions consistent with corresponding disposal requisitions, thereby allaying concerns that they, too, might have been unstable. Finally, we looked at samples from waste containers in the hood where the occurrence took place. One of these, a small amount of liquid from an almost-empty bottle labeled "100\% Nitric Acid," was identified as ethanol by GC/MS and nuclear magnetic resonance spectroscopy. Reaction between concentrated nitric acid and ethanol from this mislabeled container provided a credible explanation for the occurrence because incompatibility of these reagents is well documented. 
Facility Closure Activities (D. G. Graczyk, P. C. Lindahl, A. S. Boparai, D. L. Bowers, F. J. Martino, L. B. TenKate, J. J. Marr, A. M. Essling, K. J. Jensen, I. M. Fox, F. P. Smith, R. W. Bane, D. R. Huff, E. A. Huff, D. V. Applegate, L. L. Chromizky, S. D. Kent, Y. Tsai, K. J. Parish, M. A. Gritters, P. L. Johnson, T. TenKate, J. S. Yaeger, L. L. Smith, F. Markun, and C. S. Sabau)

Under the RCRA, facilities or areas that have been involved in the storage, treatment, or disposal of hazardous wastes must undergo a formal sequence of characterization, remediation, and recharacterization before they are returned to general use. This sequence, designated a "closure" of the affected area, is performed according to a predetermined plan prepared in collaboration with the appropriate regulatory agencies. Through its EWM Program, ANL has initiated closure activities at several on-site locations. During FY 1993, the ACL provided both laboratory research and technical support to several of these activities.

Several facilities in Building 306 were remediated. One (Room A-126) had been used for storage of hazardous wastes by ANL's Waste Management (WM) organization; another (the "Neutralization Booth") had been used for neutralization of strongly acidic or basic waste processed through WM operations. For these closures, the ACL analyzed samples of wash and rinse waters generated during the cleanup, as well as concrete and paint removed from the facilities. We determined specific contaminants (e.g., sulfide, metals), classes of contaminants (e.g., volatile organic compounds), hazardous waste characteristics as defined by RCRA (corrosivity, ignitability, reactivity, and toxicity), and radiological parameters (alpha, beta, and gamma emitters).

In the 317 area of the ANL site, the RCRA closure of two other areas was begun. One of these, the "Shoot-and-Burn Pile," consisted of a large mound of sand on which shock-reactive waste chemicals had been detonated by rifle shot in past years as a means to render the chemicals safe for disposal. The other area, the "Alkali Metal Passivation Tank," is a concrete structure that had held water for the purpose of neutralizing water-reactive chemicals. Chemical analysis of numerous samples of water, sand, soil, and sludge from these areas will be required to complete their RCRA closures. Most of these analyses involve commonly applied EPA methods. However, for the Shoot- 
and-Burn Pile, special methods had to be devised to provide data on specific materials known to have been detonated on the sand pile.

Involvement by the ACL in these RCRA closures has typically extended beyond performing laboratory measurements on samples. The ACL also participated in the selection and specification of methods for the analysis of samples, interacted with contractors that performed the sampling and remediation activities or provided third-party oversight of the closure process, and assisted in evaluation or interpretation of analysis results. Input from the contractor laboratory during the planning and performance of the closure activities, along with the data that the laboratory provides, helps to determine how waste generated during the cleanup should be disposed and whether the remediation achieved decontamination standards established in the closure plan.

Review of Quality Assurance Plans (D. A. Bass)

In FY 1993, the ACL assisted Environmental Assessment and Information Sciences Division (EID) personnel (S. S. Prasad) in the technical review of quality assurance plans for environmental restoration activities at the Aberdeen Proving Grounds. The technical support included a review of the Quality Assurance Project Plan for remedial investigation at the J-Field and review of the Chemical Quality Assurance Plan. Because of the ACL's experience with QA activities and environmental analysis requirements, we were able to make recommendations to improve the planning documents for these projects. The primary areas of review focused on activities associated with inorganic analysis. Comments from this review were incorporated into the QA plans to produce sections that complied with QA principles for environmental analysis. 
Analytical Laboratory at Aberdeen Proving Ground (D. A. Bass and A. S. Boparai)

During FY 1993, the ACL collaborated with Energy Systems Division staff (J. Schneider and K. Brubaker) in establishing an analytical laboratory to support environmental restoration activities at the Aberdeen Proving Grounds. The ACL staff assisted in designing the laboratory and configuration and floor plans. We also made recommendations on the instrumentation and methods needed to establish the capability to perform inorganic and organic analyses according to the EPA CLP Statement of Work. The ACL drew upon its experience with CLP protocols and the requirements of a laboratory performing these analyses to assist the project in preparing a detailed design of this laboratory. The laboratory design and associated recommendations for equipping the laboratory will allow the Aberdeen Proving Grounds to perform the required analyses.

\section{Environmental Audits (P. C. Lindahl)}

The ACL assisted the Environmental Assessment and Information Sciences Division in staffing one of the DOE Office of Environmental Audit (EH-24) teams that audited DOE sites during FY 1993. The ACL staff participated in the Line Program Environmental Management Audit of the Uranium Mill Tailings Remedial Action Program and was responsible for assessing the Project's formality of environmental programs and environmental program evaluation, reporting, and corrective actions. In addition, ACL staff participated in the Environmental Audit of the Laboratory for EnergyRelated Health Research. In this audit our areas of responsibility included environmental management and quality assurance.

Environmental Monitoring Program (L. B. TenKate, J. J. Marr, F. P. Smith, and L. E. Ross)

During FY 1993, the ACL prepared approximately 400 environmental water samples in support of environmental monitoring programs at ANL-East. Personnel from the Environment, Safety 


\section{$-46-$}

and Health Division (ESH) then determined metals in these digested samples by flame or graphite furnace atomic absorption spectrophotometry. During this same period, the ACL also analyzed wastewater samples collected by ESH personnel from the ANL-East site to determine oil and grease content and other parameters such as $\mathrm{pH}$ or specific conductance. Most of these measurements were required by ANL's National Pollutant Discharge Elimination System permit, although data were also obtained in support of monitoring activities for the landfill located at ANL and for hydrogeological characterization studies of the ANL site. 


\section{QUALITY ASSURANCE}

Quality Assurance/Quality Control in the ACL (F. J. Martino)

The ACL participation in a variety of multi-laboratory QA/QC programs sponsored by the EPA and DOE has provided the ACL with sets of blind Performance Evaluation (PE) samples, which are helpful in qualifying instruments and in measuring analyst performance. (The samples are termed "blind" because the analyte concentrations in these samples are known only to the EPA.) The EPA and DOE PE programs in which the ACL participated in FY 1993 included:

- The EPA Environmental Monitoring and Services Laboratory-Cincinnati (EMSL-Ci) Water Pollution Study (WPS). Blind PE samples were analyzed for cyanide, oil/grease, total dissolved and suspended solids, trace metals, $\mathrm{pH}$, specific conductance, and a variety of anions. During FY 1993, the EMSL-Ci reported that the analytical results submitted by the ACL for sample WP029 and sample WP030 showed excellent agreement with the EPA known values.

- The DOE Environmental Measurements Laboratory (EML) Quality Assessment Program and the EPA EMSL-Las Vegas Coordinated Multi-laboratory Cross-Check

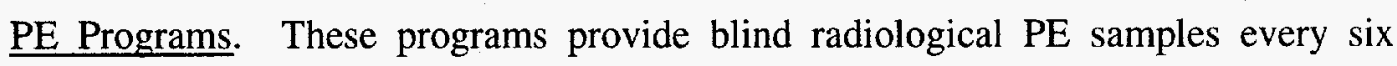
months to the ACL. Water, soil, and air-filter samples were alternately received and analyzed for radiological parameters (e.g., gross alpha-beta, gamma, tritium, Ra, U, $\mathrm{Pu}, \mathrm{Np}$ ) throughout FY 1993. The comparison of ACL results to the accepted values showed that each of the radionuclides was correctly determined by the ACL. 
- $\quad$ Cycles 4 and 5 of the WIPP Performance Demonstration Program. Headspace gas samples were received as part of the qualification maintenance procedure and were successfully analyzed for volatile organic compounds and inorganic gases.

Samples analyzed by the ACL included water, soil, sediment, sludge, oil filter paper, wood, and vegetation as the more common matrices. Environmental and waste samples usually require methods prescribed by the EPA and described in Statements of Work written for the U.S. EPA Contract Laboratory Program (CLP) or the EPA's "Test Methods for Evaluating Solid Waste" (SW846). During FY 1993, 42 full CLP-type sample data packages, consisting of analytical results and raw data, were prepared and reviewed for completeness and correctness, and forwarded to the customer for data evaluation.

The total number of ACL standard operating procedures written to address analytical methods, records management, sample tracking, administrative protocol, etc., increased from 175 to 187 in FY 1993. All are in place and available to ACL personnel in bound, multi-volume manuals strategically located throughout ACL offices and laboratory areas.

Software was previously developed for the ACL computer-assisted bar code reading system to provide quick and error-free logging of samples received for analysis, distribution, and tracking of the analytical samples, and associated documentation. This software was expanded to single samples requiring multiple analyses. The system's capabilities include providing sample notification memos, chain-of-custody forms, and summaries of samples categorized by analyses requested. Bar code scanning stations were set up in the main sample receiving area and are planned for two other laboratory areas.

Both an ACL internal management assessment and independent assessments performed by non-ACL teams provide a means to assess the quality of ACL analytical work and identify areas of potential improvement. The ACL was assessed by teams representing: (1) the ANL-East Office of 
Quality Assurance [March 1993], (2) the Waste Isolation Pilot Plant [October 1993], (3) the DOE Laboratory Management Division [February 1993], and (4) EG\&G Rocky Flats [March and August 1993]. The teams assessed implementation of the ACL Quality Assurance Plan and standard operating procedures by conducting personal interviews, reviewing record systems and documents (e.g., procurement), observing the sample tracking system, and visiting laboratories. Corrective action lists resulting from the first three of these audits were developed and implemented. 


\section{PROFESSIONAL ACTIVITIES}

A. Publications and Reports

Advances in Passive-Remote and Extractive Fourier Transform Infrared Systems

$\underline{\text { J. C. Demirgian, C. L. Hammer, Z. Mao, and E. Y. Hwang }}$

Proceedings of the 12th Incineration Conference, Knoxville, TN, May 3-17, 1993, Vol. 12, pp. 761-765 (1993)

Analytical Chemistry Laboratory Progress Report for FY 1992

D. W. Green, R. R. Heinrich, D. G. Graczyk, P. C. Lindahl, A. S.Boparai, and

D. A. Bass with contributions from ACL Staff

Argonne National Laboratory Report ANL/ACL-92/4 (December 1992)

Application of Dynamical Analysis Techniques in the Extraction of Compound-Specific Information from Fourier Transform Infrared Interferograms

S. E. Carpenter and G. W. Small

Appl. Spectrosc. $\underline{46}(12), 1790-1798$ (1992)

Detection of Sub-ng/L Actinides in Industrial Wastewater Matrices by Inductively Coupled Plasma-Mass Spectrometry

J. S. Crain and B. L. Mikesell

Appl. Spectrosc. $\underline{46}(10), 1498-1502$ (1992)

Development and Demonstration of the TRUEX Solvent Extraction Process

G. F. Vandegrift, D. B. Chamberlain, R. A. Leonard, J. C. Hutter, D. G. Wygmans,

C. Conner, J. Sedlet, L. Nuñez, J. M. Copple, J. A. Dow, B. Srinivasan,

M. C. Regalbuto, S. Weber, and L. Everson

Proceedings of the Waste Management '93 Conf., Tuscon, AZ,

February 28-March 4, 1993, Vol. 2, pp. 1045-1050 (1993)

Electric Vehicle Battery Testing and Development at Argonne National Laboratory, 1991 Annual Report

W. H. DeLuca, J. A. Smaga, K. R. Gillie, C. E. Webster, A. F. Tummillo,

J. E. Kulaga, and J. J. Marr

Electric Power Research Institute Report EPRI TR-101371 (December 1992)

Epitaxial Growth of $\mathrm{YbBa}_{2} \mathrm{Cu}_{3} \mathrm{O}_{7-\delta}$ Films on (100)-Oriented $\mathrm{MgO}$ and $\mathrm{SrTiO}_{3}$ Substrates by Oxidation of a Liquid Alloy Precursor

N. Merchant, J. S. Luo, V. A. Maroni, D. M. Gruen, B. S. Tani, S. Sinha,

K. H. Sandhage, and C. A. Creven

J. Mater. Res. $\underline{7}(10), 2680-2688$ (1992) 
Kinetics and Mechanism of the $(\mathrm{Bi}, \mathrm{Pb})_{2} \mathrm{Sr}_{2} \mathrm{Ca}_{2} \mathrm{Cu}_{3} \mathrm{O}_{10}$ Formation Reaction in SilverSheathed Wires

J. S. Luo, N. Merchant, V. A. Maroni, D. M. Gruen, B. S. Tani, W. L. Carter, and G. N. Riley

Appl. Supercond. 1(1/2), 101-107 (1993)

On-Line Monitoring of Incinerator Emissions

Z. Mao, J. Demirgian, and E. Hwang

Proceedings of the 12th Annual 1993 Incineration Conference, Knoxville, TN, May 3-7, 1993, Vol. 12, pp 755-760 (1993)

Phase Chemistry and Microstructure Evolution in Silver-Clad $\left(\mathrm{Bi}_{2-\mathrm{x}} \mathrm{Pb}_{\mathrm{x}}\right) \mathrm{Sr}_{2} \mathrm{Ca}_{2} \mathrm{Cu}_{3} \mathrm{O}_{\mathrm{y}}$ Wires J. S. Luo, N. Merchant, E. Escorcia-Aparicio, V. A. Maroni, D. M. Gruen, B. S. Tani, G. N. Riley, and W. L. Carter

IEEE Trans. Appl. Superconduc. $\underline{3}(1), 972-975$ (1993)

Radium Isotope Geochemistry of Thermal Waters, Yellowstone National Park, Wyoming, USA

N. C. Sturchio, J. K. Bohlke, and F. Markun

Geochim. Cosmochim. Acta 57, 1203-1214 (1993)

The Stability of Calibration Standards for ICP/AES Analysis: Six-month Study

E. H. Huff and D. R. Huff

Argonne National Laboratory Report ANL/ACL-92/3 (May 1992)

B. Oral Presentations

Advances in Passive-Remote and Extractive Fourier Transform Infrared Spectroscopic Systems

J. C. Demirgian, C. L. Hammer, and E. Y. Hwang

Presented at the 44th Pittsburgh Conference and Exposition on Analytical

Chemistry and Applied Spectroscopy, Atlanta, GA, March 8-12, 1993

Analyses of IFR Matrices--Problems and Solutions

E. A. Huff and D. R. Huff

Presented at the First Workshop on the Analytical Chemistry of the IFR

Process, Argonne National Laboratory-West, Idaho Falls, ID,

March 1-3, 1993

Analysis of Paint Samples--A Comparative Study Using FTIR Microspectroscopy and SEM-EDX

\section{T. Snyder}

Presented at the 18th ACL Technical Meeting, Argonne National

Laboratory, Argonne, IL, February 25, 1993 
Analysis of Samples from Integral Fast Reactor (IFR) Program at ANL-East D. L. Bowers and C. S. Sabau

Presented at the First Workshop on Analytical Chemistry of the IFR Pyroprocess, Argonne National Laboratory-West, Idaho Falls, ID, March 1-3, 1993

Analytical Chemistry at Argonne National Laboratory and the Need for Environmental Analysis

D. A. Bass

Presented at the Illinois Institute of Technology, Chicago, IL, March 31, 1993

Analytical Chemistry Needs of the Fuel Cycle Facility Electrorefiner

E. C. Gay, D. L. Bowers, and W. E. Miller

Presented at the First Workshop on Analytical Chemistry of the IFR Pyroprocess, Argonne National Laboratory-West, Idaho Falls, ID, March 1-3, 1993

Detection of Chemical Plumes Utilizing Passive-Remote Fourier Transform Infrared (FTIR) Spectroscopy

J. C. Demirgian, C. L. Hammer, and W. Killian

Presented at the 44th Pittsburgh Conference and Exposition on Analytical Chemistry and Applied Spectroscopy, Atlanta, GA, March 8-12, 1993

Determining Environmental Radioactivity: A New Challenge in the ICP-MS Laboratory J. S. Crain

Presented at the Fisons Regional ICP-MS Seminar, Itasca, IL, May 5, 1993

Development of an Integrated Performance Evaluation Program (IPEP) for the Department of Energy's Office of Environmental Restoration and Waste Management

W. E. Streets, D. Bottrell, R. Newberry, C. Klusek, S. Morton, K. Karp, and P. C. Lindahl

Presented at the 20th Annual National Energy and Environmental Quality Division Conference for the American Society for Quality Control (ASQC), Indian Wells, CA, September 19-24, 1993

Development of Organic Methods for Mixed Waste Samples

E. Y. Hwang, L. L. Lamoureux, D. V. Applegate, K. J. Parish, S. D. Kent, and A. S. Boparai

Presented at the 33rd ORNL/DOE Conference on Analytical Chemistry in Energy Technology, Gatlinburg, TN, October 6-8, 1992

Direct Determination of Impurities in Actinide Matrices by Inductively Coupled PlasmaMass Spectrometry

J. S. Crain, D. L. Gallimore, and K. P. Coffelt

Presented at the First Workshop on the Analytical Chemistry of the IFR Process, Argonne National Laboratory-West, Idaho Falls, ID, March 1-3, 1993 
Effects of Radiation Exposure on SRL Glass 131 Composition Alteration in a Steam Environment

D. J. Wronkiewicz, L. M. Wang, J. K. Bates, and B. S. Tani

Presented at the Fall Meeting of the Materials Research Society, Boston, MA, November 30-December 4, 1992

Environmental Analytical Chemistry at Argonne National Laboratory

D. A. Bass

Presented at the Earth Day at the University of Northern Iowa, Cedar Falls, IA, April 22, 1993

Field Identification and Quantitation of Volatile Organics in Soils Utilizing Fourier Transform Infrared Spectroscopy

J. C. Demirgian, M. Clapper-Gowdy, and G. Robittaille

Presented at the National Symp. on Measuring and Interpreting VOCs in

Soils: State of the Art and Research Needs, Las Vegas, NV,

January 12-14, 1993

Fourier Transform Infrared (FTIR) Microspectroscopy: A Cost Effective Approach to Characterizing Unknown Liquid Waste Samples

C. T. Snyder

Presented at the 44th Pittsburgh Conference and Exposition on Analytical

Chemistry and Applied Spectroscopy, Atlanta, GA, March 8-12, 1993

Implementation of Thermal Desorption Fourier Transform Infrared Spectroscopy in the Direct Analysis of Soil Samples for Semivolatile and Volatile Organics

M. Clapper-Gowdy, J. C. Demirgian, and J. W. Tang

Presented at the 18th Analytical Chemistry Laboratory Technical Meeting, Argonne National Laboratory, February 25, 1993

Implementation of Thermal Desorption Fourier Transform Infrared Spectroscopy in the Direct Analysis of Soil Samples for Semivolatile and Volatile Organics

M. Clapper-Gowdy, J. C. Demirgian, and J. W. Tang

Presented at the 44th Pittsburgh Conference and Exposition on Analytical

Chemistry and Applied Spectroscopy, Atlanta, GA, March 8-12, 1993

Inductively Coupled Plasma-Mass Spectrometry: Application to DOE Environmental Restoration and Waste Management

J. S. Crain, J. Hansel, J. Troxel, and B. Mikesell

Presented at the 33rd ORNL/DOE Conference on Analytical Chemistry in Energy Technology, Gatlinburg, TN, October 6-8, 1992

Mass Spectrometric Measurement of Uranium and Plutonium Isotope Ratios for Determining Isotopic Composition and for Precise Assays by Isotope Dilution

D. G. Graczyk

Presented at the First Workshop on the Analytical Chemistry of the IFR

Process, Argonne National Laboratory-West, Idaho Falls, ID,

March 1-3, 1993 
Particle Beam Liquid Chromatography/Mass Spectrometry

S. D. Kent

Presented at the 18th Analytical Chemistry Laboratory Technical Meeting, Argonne National Laboratory, Argonne, IL, February 25, 1993

Phase Formation of $\left(\mathrm{Bi}_{1-x} \mathrm{~Pb}_{x}\right)_{2} \mathrm{Sr}_{2} \mathrm{Ca}_{2} \mathrm{Cu}_{3} \mathrm{O}_{\mathrm{y}}$ in Silver-Clad Wires

J. S. Luo, N. Merchant, V. A. Maroni, D. M. Gruen, B. S. Tani, G. N. Riley, and W. L. Carter

Presented at the Annual Meeting of the Minerals, Metals, and Materials

Soc. Symp., Denver, CO, February 21-25, 1993

Portable X-Ray Fluorescence for Determination of Lead and Other Metals on Small-Arms Firing Ranges

J. F. Schneider, J. D. Taylor, S. D. Zellmer, and D. A. Bass

Presented at the 33rd ORNL/DOE Conference on Analytical Chemistry in Energy Technology, Gatlinburg, TN, October 6-8, 1992

Quality Assurance Program for DOE's Analytical Services Program

P. C. Lindahl

Presented at the DOE Analytical Laboratory Managers Meeting, Oak

Ridge, TN, October 21-22, 1992

Radiochemical Analysis of the EBWR Reactor Vessel Wall

D. L. Bowers

Presented at the 17th Analytical Chemistry Laboratory Technical Meeting, Argonne National Laboratory, Argonne, IL, November 5, 1992

Rietveld Refinement of X-ray Powder Diffraction Data

P. L. Johnson

Presented at the 17th Analytical Chemistry Laboratory Technical Meeting, Argonne National Laboratory, Argonne, IL, November 5, 1992

Special Considerations in the Analysis of Mixed Waste Samples

E. Y. Hwang

Presented at the 17th Analytical Chemistry Laboratory Technical Meeting, Argonne National Laboratory, Argonne, IL, November 5, 1992

The Stability of Calibration Standards for ICP/AES Analysis

D. R. Huff and E. A. Huff

Presented at the 33rd ORNL/DOE Conference on Analytical Chemistry in Energy Technology, Gatlinburg, TN, October 6-8, 1992

The Stability of Calibration Standards for ICP/AES Analysis

D. R. Huff and E. A. Huff

Presented at the 17th Analytical Chemistry Laboratory Technical Meeting, Argonne National Laboratory, Argonne, IL, February 25, 1993 
Stability of Low Concentration Calibration Standards for Graphite Furnace Atomic Absorption

\section{B. TenKate}

Presented at the 17th Analytical Chemistry Laboratory Technical Meeting, Argonne National Laboratory, Argonne, IL, November 5, 1992

Stability of Low Concentration Calibration Standards for Graphite Furnace Atomic Absorption Spectroscopy

D. A. Bass and L. B. TenKate

Presented at the 33rd ORNL/DOE Conference on Analytical Chemistry in

Energy Technology, Gatlinburg, TN, October 6-8, 1992

Standoff Detection of Chemical Plumes Using Passive-Remote Fourier Transform Infrared Spectroscopy

\section{J. C. Demirgian}

Presented at the DOE Expo '93 Conference and Exhibit, Oak Ridge

National Laboratory, Oak Ridge, TN, May 3-7, 1993

Thermal Desorption Fourier Transform Infrared Spectroscopy for the Direct Analysis of Soil Samples Containing Semivolatile and Volatile Organic Compounds

J. C. Demirgian, M. Clapper-Gowdy, L. M. Tober, J. W. Tang, and G. Robitaille Presented at the 44th Pittsburgh Conference and Exposition on Analytical Chemistry and Applied Spectroscopy, Atlanta, GA, March 8-12, 1993

Treatment of Aqueous Mixed Wastes Containing RCRA Metals

J. C. Hutter, H. No, D. G. Wygmans, D. B. Chamberlain, C. Conner,

C. Srinivasan, R. A. Leonard, L. Nuñez, J. Sedlet, and G. F. Vandegrift

Presented at the Second Int. Mixed Waste Symp., Baltimore, MD, August 16-20, 1993

Treatment of Radioactive Liquid Waste at Argonne National Laboratory

H. No, D. G. Wygmans, D. B. Chamberlain, C. Conner, J. C. Hutter,

R. A. Leonard, L. Nuñez, J. Sedlet, and G. F. Vandegrift

Presented at the Second Int. Mixed Waste Symp., Baltimore, MD, August 16-20, 1993

Volatile Organic Analysis of Mixed Waste Samples

L. L. Chromizky

Presented at the 17th Analytical Chemistry Laboratory Technical Meeting, Argonne National Laboratory, Argonne, IL, February 25, 1993

\section{Meetings Attended}

\section{Dean A. Bass}

9th Annual Waste Testing and Quality Assurance Symposium, Arlington, VA, July 12-17, 1993 
Delbert L. Bowers

ASTM Meeting, Committee C-26, San Antonio, TX, January 17-22, 1993

David W. Green

10th DOE Analytical Managers Meeting, Oak Ridge, TN, October 20-22, 1992 , Session Chairman

33rd ORNL-DOE Conference on Analytical Chemistry in Energy Technology, Gatlinburg, TN, October 6-8, 1992

International Association of Environmental Testing Laboratories, Stakeholders Workshop on Mixed Wastes and Radiochemistry Analyses, McLean, VA, October 27-29, 1992

$\underline{\text { Paul L. Johnson }}$

Argonne National Laboratory Symposium for Undergraduates in Science, Engineering, and Mathematics, Argonne, IL, November 6-7, 1992, Session Chairman

Peter C. Lindahl

EM-563 Program Review, Bethesda, MD, March 30-April 1, 1993

Workshop on Characterization of Containerized Mixed Low-Level Wastes, Las Vegas, NV, May 25-27, 1993, Session Co-chairman

\section{W. Elane Streets}

Interagency Workshop on the Lifecycle of a Database, Las Vegas, NV, May 4-6, 1993

D. Professional Organizations

Dean A. Bass

American Chemical Society

Sigma Xi

Society for Applied Spectroscopy

Amrit S. Boparai

American Chemical Society

Sigma Xi

Delbert L. Bowers

American Chemical Society

American Society for Testing and Materials 
$\underline{\text { Scott E. Carpenter }}$

American Chemical Society

North American Chapter of the International Chemometrics Society

Maureen Clapper-Gowdy

American Chemical Society

Society for Applied Spectroscopy

Jeffrey S. Crain

American Chemical Society

Division of Analytical Chemistry

Jack C. Demirgian

American Chemical Society

Air and Waste Management Association

Technical Association of the Pulp and Paper Industry

Irene M. Fox

Society for Applied Spectroscopy

Association for Women in Science

Sigma Xi

Donald G. Graczyk

American Chemical Society

Sigma Xi

American Society for Mass Spectrometry

David W. Green

American Chemical Society

Division of Analytical Chemistry

Analytical Laboratory Managers Association, Board of Directors

Sigma Xi

Doris R. Huff

Phi Beta Kappa 
Edmund A. Huff

American Chemical Society

American Society for Testing and Materials

Society for Applied Spectroscopy

Sigma Xi

Paul L. Johnson

American Crystallographic Association

Association for Computing Machinery

Sigma Xi, ANL Chapter Secretary

Peter C. Lindahl

American Chemical Society

Division of Analytical Chemistry

Division of Fuel Chemistry

Society for Applied Spectroscopy

Francis Markun

Health Physics Society

Midwest Chapter of Health Physics Society

Gerald T. Reedy

American Chemical Society

Society for Applied Spectroscopy

Carmen S. Sabau

American Chemical Society

Nuclear Chemistry and Technology

Chicago Section

American Nuclear Society

Fuel Cycle and Waste Management Division

Chicago Section

American-Romanian Academy of Arts and Sciences

Association of Women in Science

Chicago Chapter

New York Academy of Sciences

Sigma Xi 
Florence P. Smith

National Organization of Black Chemists and Chemical Engineers

Christine T. Snyder

American Chemical Society

W. Elane Streets

American Society for Testing and Materials

American Society for Quality Control

Lynn B. TenKate

Society for Applied Spectroscopy

Sigma Xi

Tony TenKate

American Association of Physics Teachers

Sigma Xi

E. Professional Training

Alice M. Essling

Advanced Microwave Sample Preparation, CEM Corporation, North Carolina, October 12-13, 1992

F. $\quad$ ACL Seminars

ICP for Online Process Control: Status and Developments

Dr. Gerhard A. Meyer, Battelle Memorial Institute October 1, 1992

Unvented Thermal Process for Treating Mixed Waste

Dr. Paul Nelson, Argonne National Laboratory

October 15, 1992

Elemental and Isotopic Analysis and Measurement of Elemental Speciation by Inductively Coupled Plasma-Mass Spectrometry

Dr. R. Samuel Houk, Iowa State University June 15, 1993

The AMTEX Partnership: Plans and Opportunities

Dr. N. F. Sather, Argonne National Laboratory

August 12, 1993 
$-60-$

Expedited Site Characterization: A Rapid, Cost-Effective Process for Preremedial Site Characterization

Dr. J. C. Burton, Argonne National Laboratory September 14, 1993 
Distribution for ANL/ACL-93/2

Internal:

J. P. Ackerman

P. Aggarwal

I. Ahmad

O. O. Ajayi

I. Ambats

D. V. Applegate

J. Argyrakis

J. G. Asbury

M. D. Atella

L. Baker

U. Balachandran

R. W. Bane

S. G. Barisas

D. L. Barney

S. H. Barr

D. A. Bass

J. K. Bates

C. H. Batson

J. E. Battles

C. A. Bebrich

W. Nelson Beck

W. Berg

N. J. Beskid

P. R. Betten

M. H. Bhattacharyya

S. K. Bhattacharyya

N. Bhatti

M. Blander

L. E. Boing

D. H. Bomkamp

P. Bonsignore

A. S. Boparai

S. S. Borys

D. L. Bowers

D. R. Bradley

B. S. Brown

E. A. Brown

K. L. Brubaker

F. Brunner

D. E. Busch

F. A. Cafasso

D. W. Carnegie
S. E. Carpenter

Y. I. Chang

M. J. Chen

K. Chiu

L. L. Chromizky

J. H. Cleland

J. T. Collins

R. E. Combs

J. S. Crain

E. J. Croke

D. Cummings

J. C. Cunnane

L. W. Deitrich

J. C. Demirgian

C. B. Dennis

M. H. Derbidge

J. S. Devgun

C. E. Dickerman

D. R. Diercks

M. L. Dietz

J. D. Ditmars

S. Dorris

H. Drucker

F. J. Dudek

B. D. Dunlap

J. D. Dutemple

A. J. Dvorak

C. Dwight

W. L. Ebert

D. E. Edgar

B. Ercoli

A. Erdemir

M. D. Erickson

A. M. Essling

S. L. Ettinger

J. K. Fink

I. M. Fox

F. Y. Fradin

J. Frank

S. Frank

E. C. Gay

N. L. Goetz
N. W. Golchert

I. Goldberg

A. J. Goldman

H. T. Goodspeed

D. G. Graczyk

C. Grandy

D. W. Green (50)

J. P. Greene

G. E. Griffin

K. C. Gross

D. M. Gruen

G. R. Gunderson

W. H. Gunther

W. H. Hannum

M. C. Hansen

J. B. Harkness

J. E. Harmon

H. M. Hartmann

D. A. Haugen

H. J. Haupt

R. R. Heinrich

J. E. Helt

W. F. Henning

J. E. Herceg

D. J. Hill

A. G. Hins

M. J. Holzeme

E. P. Horwitz

H.-S. Huang

E. Huberman

E. A. Huff

D. R. Huff

J. C. Hutter

E. Y. Hwang

L. Iton

M. J. Janik

D. J. Jankowski

J. D. Jastrwo

K. J. Jensen

B. J. Jody

G. K. Johnson

C. E. Johnson 

D. O. Johnson
C. A. Melendres
G. T. Reedy
P. L. Johnson
V. A. Mendez (10)
C. A. Reilly
J. Johnson
S. Johnson
T. R. Johnson
W. C. Metz
M. Michlik
D. Karrelas
S. F. Miller
S. J. Riley
M. J. Robinet
W. E. Miller
B. J. Roop
T. F. Kassner
D. E. Moncton
G. G. Ketchmark
L. Moos
A. M. Kini
L. R. Morss
R. W. Rose
E. R. Kinney
C. E. Klotz
R. G. Kolzow
C. F. Konicek
H. S. Morss
T. P. Mulcahey
E. A. Myatt
K. M. Myles
A. J. Kras
A. R. Krauss
J. Krazinski
H. W. Myron
Z. Nagy
J. R. Krsul
B. W. Nashold
T. C. Kuhfuss
C. Negri
L. A. Neimark
R. Kumar
M. L. Kyle
M. Lachman
J. J. Laidler
T. A. Lang
K. K. Larsen
P. A. Nelson
D. M. Nelson
R. D. Nixon
H. J. No
J. W. O'Kelley
D. Larson
Y. Orechwa
D. Pancake
R. A. Leonard
K. J. Parish
K. H. Leong
L. G. LeSage
M. A. Lewis
P. C. Lindahl
M. J. Lineberry
C. Q. Liu
C. D. Livengood
D. C. Parzyck
T. L. Patton
L. E. Ross
P. Rumps
B. Ruscic
C. S. Sabau
N. A. Sacco-Gibson
N. F. Sather
W. W. Schertz
R. A. Schlenker
R. M. Schletter
M. W. Schlueter
J. F. Schneider
A. Schriesheim
W. J. Schulze
T. L. Scott
J. Sedlet
J. L. Settle
W. J. Shack
G. K. Shenoy
E. Shoemaker
S. Siegel
M. A. Slawecki
J. G. Peak
J. G. Sleeth
D. L. Smith
D. R. Pedersen
M. J. Pellin
R. Peters
M. Petrick
R. F. Malecha
K. C. Picel
C. A. Malefyt
F. Markun
V. A. Maroni
J. J. Marr
F. J. Martino
J. J. Mazer
J. R. McCreary
B. F. Picologlou
D. L. Smith
F. P. Smith
L. L. Smith
R. K. Smither
J. L. Snelgrove
J. A. Snow
B. G. Pierce
C. T. Snyder
R. D. Pierce
M. A. Sodaro
R. E. Piorkowski
R. W. Springer
D. S. Poa
W. F. Podolski
B. Srinivasan
R. B. Poeppel
S. McDeavitt
W. D. McFall
A. J. Policastro
R. E. Stajdohar
V. C. Stamoudis
Y. L. Qian
M. J. Steindler
H. F. McFarlane
S. Rabidou
C. M. Stevens
L. M. Stock
R. J. McMahon
J. B. Rajan
J. W. Meadows
A. C. Raptis
W. E. Streets
K. Sugano 
T. G. Surles

W. M. Swift

T. A. Taiwo

B. S. Tani

J. D. Taylor

F. G. Teats

L. B. TenKate

T. TenKate

R. J. Teunis

J. R. Thuot

C. E. Till

D. V. Tolle

D. Tomasko

Z. Tomczuk

A. Travelli

C. L. Trybus

Y. Tsai

D. D. Tussing

J. P. Unik
R. A. Valentin

G. F. Vandegrift

R. Venkatadri

E. Vinokour

K. S. Vorres

W. R. Vroman

D. C. Wade

L. C. Walters

Z.-B. Wang

D. W. Warren

J. F. Weber

R. W. Weeks

D. W. Werst

M. L. Wesely

F. A. Westholm

A. M. White

C. L. Wilkinson

C. W. Williams

R. Gary Williams
J. M. Williams

J. L. Willit

A. Wilson

R. E. Winans

G. E. Woloschak

R. D. Wolson

J. L. Woodring

A. E. Wright

D. J. Wronkiewicz

R. A. Wynveen

J. S. Yaeger

S. C. L. Yin

R. K. Yoo

C.-Y. Yuen

S. Zellmer

S. K. Zussman

TIS Files

External:

DOE-OSTI (2)

ANL-E Library (2)

ANL-W Library

Manager, Chicago Operations Office, DOE
A. Bindokas, DOE-CH
M. Bollinger, DOE-CH
D. Dashevsky, DOE-CH
J. Haugen, DOE-CH
J. O. Hunze, DOE-CH
M. J. Klimas, DOE-CH
R. E. Lang, DOE-CH
J. B. Roberts, DOE-CH
J. R. LaFevers, DOE-UC
D. Green, DOE-CH/AAO

A. L. Taboas, DOE-CH/AAO

Chemical Technology Division Review Committee Members:

E. R. Beaver, Monsanto Company, St. Louis, MO

D. L. Douglas, Consultant, Bloomington, $\mathrm{MN}$

R. K. Genung, Oak Ridge National Laboratory, Oak Ridge, TN

J. G. Kay, Drexel University, Philadelphia, PA

G. R. St. Pierre, Ohio State University, Columbus, $\mathrm{OH}$

J. Stringer, Electric Power Research Institute, Palo Alto, CA

J. B. Wagner, Arizona State University, Tempe, AZ 
A. Alford-Stevens, U.S. Environmental Protection Agency, EMSL, Cincinnati, OH

T. A. Baillieul, Battelle Columbus Laboratories, Columbus, $\mathrm{OH}$

P. Baisden, Lawrence Livermore National Laboratory, Livermore, CA

G. A. Baudino, Santa Fe, NM

T. Beasley, U. S. Environmental Measurements Lab., New York, NY

R. E. Berkeley, U.S. Environmental Protection Agency, Research Triangle Park, NC

C. D. Bingham, New Brunswick Laboratory, Argonne, IL

D. Bogen, USDOE, New York, NY

D. Bottrell, USDOE, Gaithersburg, MD

M. Carter, USDOE, Gaitherburg, MD

N. F. Christopher, Martin Marietta Energy Systems, Piketon, OH

V. Church, EG\&G Rocky Flats Plant, Golden, CO

G. Clark, Reynolds Electric \& Engineering, Las Vegas, NV

A. S. Clark, Department of the Army, Vicksburg, MS

C. E. Coffey, Westinghouse Savannah River Company, Aiken, SC

M. Connolly, INEL EG\&G Idaho, Inc., Idaho Falls, ID

J. Connolly, INEL EG\&G Idaho, Inc., Idaho Falls, ID

R. Conzemius, Ames Laboratory, Iowa State University, Ames, IA

P. T. Cunningham, Los Alamos National Laboratory, Los Alamos, NM

J. L. Daniel, Battelle Pacific Northwest Laboratory, Richland, WA

H. J. Dewey, Los Alamos National Laboratory, Los Alamos, NM

G. Dials, Albuquerque Field Office, Waste Isolation Pilot Plant, Carlsbad, NM

B. I. Diamondstone, Natural Institute of Standards and Technology, Gaithersburg, MD

J. Dick, Rocky Flats Plant, Golden, CO

D. A. Dodd, Westinghouse Hanford Company, Richland, WA

J. G. Donnon, Savannah River Plant, Aiken, SC

J. G. Dorsey, Martin Marietta Energy Systems, Oak Ridge, TN

D. J. Duchamp, The Upjohn Company, Kalamazoo, MI

M. Duff, WIPP Project Integration Office, Albuquerque, NM

P. A. Duhamel, USDOE, Office of Health and Environmental Research, Germantown, MD

A. Edelman, USDOE, Office of Energy Research, Germantown, MD

M. Edelson, Ames Laboratory, Iowa State University, Ames, IA

C. Elly, U. S. Environmental Protection Agency, Chicago, IL

D. J. Fauth, Analytical Lab West Valley Nuclear Services, West Valley, NY

C. Fellers, Mound Laboratory, Miamisburg, $\mathrm{OH}$

J. Fortuna, Drug Enforcement Administration, Lorton, CA

C. W. Frank, USDOE, Office of Technology Development, Washington, DC

J. Goldstein, USDOE, Office of Health and Environmental Research, Germantown, MD

S. Gordon, IITRI, Chicago, IL

T. Grady, U.S. Environmental Protection Agency, Las Vegas, NV

T. C. Greengard, Rocky Flats Plant, Golden, CO

W. Griest, Oak Ridge National Laboratory, Oak Ridge, TN

T. Grumbly, USDOE, Office of Environmental Management, Washington, DC

G. A. Hansen, U.S. Environmental Protection Agency, Washington, DC

J. Harness, USDOE, Morgantown Energy Technology Center, Morgantown, WV

K. Henry, Lab Support, Tinley Park, IL 
D. L. Herman, Westinghouse Materials Company of Ohio, Cincinnati, OH

D. C. Hockman, WMX Environmental Monitoring Laboratories, Inc., Geneva, IL

D. Holmes, DOE Carlsbad Area Office, Carlsbad, NM

R. S. Houk, Ames Laboratory, Iowa State University, Ames, IA

D. Hunter, Rockwell International, Golden, CO

J. Jessup-Arvizu, CONTECH, Inc., Albuquerque, NM

J. R. Jordan, Analytical Consumer, Carlisle, MA

W. Killian, Ferris State University, Big Rapids, MI

A. G. King, Pacific Northwest Laboratories, Richland, WA

B. Kowalski, University of Washington, Seattle, WA

P. Krey, USDOE, Environmental Measurements Labs, New York, NY

J. M. Latkovich, Battelle Pacific Northwest Laboratory, Richland, WA

C. S. Leasure, Los Alamos National Laboratory, Los Alamos, NM

R. G. Lewis, U.S. Environmental Protection Agency, Research Triangle Park, NC

L. C. Lewis, Westinghouse Idaho Nuclear Company, Idaho Falls, ID

D. Lillian, USDOE, Gaithersburg, MD

C. A. Lucchesi, Northwestern University, Evanston, IL

R. M. Lugar, Idaho National Engineering Laboratory, EG\&G Idaho, Inc., Idaho Falls, ID

T. Lyttle, Tulane University, New Orleans, LA

M. M. Mamoun, Gas Research Institute, Chicago, IL

C. Marcelo, New Brunswick Laboratory, Argonne, IL

M. Matthews, DOE Carlsbad Area Office, Carlsbad, NM

W. A. McClenny, U.S. Environmental Protection Agency, Research Triangle Park, NC

G. B. Mellinger, Pacific Northwest Laboratory, Richland, WA

S. Messenger, Morton Arboretum, Lisle, IL

A. Montana, Warner-Lambert Parke-Davis, Morris Plains, NJ

R. W. Morrow, Martin Marietta Energy Systems, Oak Ridge, TN

S. Morton, USDOE, Idaho Operations Office, Idaho Falls, ID

J. D. Mulik, U.S. Environmental Protection Agency, Research Triangle Park, NC

R. Murray, USDOE, Office of Technology Development, Germantown, MD

W. Newberry, USDOE, Office of Technology Development, Germantown, MD

L. Newman, Brookhaven National Laboratory, Upton, NY

R. D. Oldham, New Brunswick Laboratory, Argonne, IL

M. Pennington, Allied Signal, Kansas City, MO

J. Phillips, Los Alamos National Laboratory, Los Alamos, NM

J. D. Pleil, U.S. Environmental Protection Agency, Research Triangle Park, NC

G. Plummer, Entropy Environmentalist, Inc., Research Triangle Park, NC

F. Podosek, Washington University, St. Louis, MO

J. Poppiti, USDOE, Office of Hanford Waste Management Operations, Washington, DC

C. Purdy, USDOE, Office of Technology Development, Germantown, MD

J. W. Pyper, Lawrence Livermore National Laboratory, Livermore, CA

J. M. Ramirez, Allied-Signal, Inc., Kansas City, MO

G. D. Robbins, Martin Marietta Energy Systems, Oak Ridge, TN

C. Ross, U.S. Environmental Protection Agency, Chicago, IL

P. Russ, Lawrence Livermore National Laboratory, Livermore, CA

C. Schelble, EG\&G Rocky Flats Plant, Golden, CO 
E. Schmieman, Pacific Northwest Laboratory, Richland, WA

K. Schoendaller, EG\&G Rocky Flats, Inc., Golden, CO

R. Scott, USDOE, Environmental Quality Assurance \& Quality Control, Washington, DC J. Q. Searcy, Sandia National Laboratories, Albuquerque, NM

A. T. Sherren, North Central College, Naperville, IL

J. Smith, University of Chicago, Chicago, IL

W. A. Spencer, Westinghouse Savannah River Company, Aiken, SC

J. R. Stetter, Transducer Research, Inc., Palos Hills, IL

F. D. Stevenson, USDOE, Office of Basic Energy Sciences, Germantown, MD

C. Stroup, Westinghouse Hanford Company, Richland, WA

J. Strouse, Department of Chemistry, University of California, Los Angeles, CA

L. Sygitowicz, Reynolds Electrical \& Engineering Co., Las Vegas, NV

A. Tardiff, USDOE, Office of Technology Development, Germantown, MD

J. Tillman, WTAC, WIPP Technical Assistance Contractor, Carlsbad, NM

N. Trahey, National Institute of Standards and Technology, Gaithersburg, MD

R. Villarreal, Los Alamos National Laboratory, Los Alamos, NM

H. A. Vincent, U.S. Environmental Protection Agency, EMSL-LV, Las Vegas, NV

W. M. Walsh, Health Research Institute, Naperville, IL

W. C. Weimer, Battelle Pacific Northwest Laboratory, Richland, WA

S. Weissman, Sandia National Laboratory, Albuquerque, NM

R. P. Whitfield, USDOE, Office of Environmental Restoration, Washington, DC

C. G. Whitworth, MSE, Inc., Butte, MT

J. Williams, DOE Carlsbad Area Office, Carlsbad, NM

R. J. Wingender, Dexter Corporation, Waukegan, IL

P. D. Wooldridge, Paducah Gaseous Diffusion Plant, Paducah, KY

K. L. Wright, Waste Policy Institute, Germantown, MD

J. Zarret, EG\&G Rocky Flats Plant, Golden, CO 